\title{
Effects of the COVID-19 Pandemic on Farmers and Their Responses: A Study of Three Farming Systems in Kerala, South India
}

\author{
Anamika Menon ${ }^{1}$ and Dietrich Schmidt-Vogt ${ }^{2, *}$ \\ 1 Ashoka Trust for Research in Ecology and the Environment (ATREE), Bengaluru 560064, India; \\ anamika.menon@atree.org \\ 2 Faculty of Environment and Natural Resources, Freiburg University, 79106 Freiburg, Germany \\ * Correspondence: dietrich.schmidt-vogt@waldbau.uni-freiburg.de
}

check for updates

Citation: Menon, A.; Schmidt-Vogt, D. Effects of the COVID-19 Pandemic on Farmers and Their Responses: A Study of Three Farming Systems in Kerala, South India. Land 2022, 11, 144. https://doi.org/10.3390/ land11010144

Academic Editor: Elisa Marraccini

Received: 17 November 2021

Accepted: 6 January 2022

Published: 17 January 2022

Publisher's Note: MDPI stays neutral with regard to jurisdictional claims in published maps and institutional affiliations.

Copyright: (c) 2022 by the authors. Licensee MDPI, Basel, Switzerland. This article is an open access article distributed under the terms and conditions of the Creative Commons Attribution (CC BY) license (https:/ / creativecommons.org/licenses/by/ $4.0 /)$.

\begin{abstract}
Particularly in countries with an agrarian economy, the COVID-19 pandemic has brought hardships faced by farmers into sharp focus. One of the most badly hit countries was India. This study aims to bring to light the effects of the COVID-19 pandemic on the livelihoods of farmers in three farming systems (coffee farming, Kole wetland paddy farming, and homestead farming) in the southern Indian state of Kerala. We collected the data using telephone interviews and studied the impacts (economic, social, institutional) of the pandemic on the selected farming systems, the responses of farmers (short and long term) to these impacts, and the ability of farmers to secure their livelihoods (by analyzing resilience capacities and transforming structures and processes of the farming systems). The methodological framework used was developed based on the Sustainable Livelihoods Approach and the Resilience Framework. We found significant impacts on the three studied farming systems due to COVID-19. As the impacts, responses, and ability to secure livelihoods varied across the three farming systems, we concluded that there is not a single solution that could be prescribed for all farming systems and that each land use system must be treated individually.
\end{abstract}

Keywords: COVID-19 pandemic impact; farmer responses; livelihoods; resilience; Kerala

\section{Introduction}

COVID-19 caused by the SARS COV-2 virus was declared a global pandemic by the World Health Organisation (WHO) on 11 March 2020. The unanticipated reach and scale of the economic downturn caused by the pandemic plunged the world and most countries into economic recession in 2020, with per capita incomes contracting in more countries than at any time in the recent past. People employed in the informal sectors in many countries around the world saw their incomes significantly reduced or disappear.

The first COVID-19 case was reported in India in the state of Kerala on 27 January 2020 [1]. All commercial activities and domestic and international flights were suspended in March and the country went into lockdown on 24 March 2020. In the first wave of the pandemic, 10 million people were infected, with around 150,000 deaths [2]. This figure does not include people who died due to the indirect impacts of the pandemic, such as loss of jobs and food insecurity. The indirect impacts of the virus, the subsequent lockdown, and the associated stagnant economy have led many into poverty. After the pandemic struck, India saw the single largest drop in GDP in the country's history. From April to June 2020, India's GDP slumped by $24.4 \%$ [3].

Particularly in countries with an agrarian economy, the COVID-19 pandemic has brought hardships faced by farmers into sharp focus. Poverty, hunger, debts, and farm bankruptcies had been prevalent in these countries before but were aggravated during the pandemic [4]. With a population of 1.3 billion people and more than 200 million people living in extreme poverty [5], India was especially badly hit by the pandemic. In India, the 
pandemic crisis also exposed severe food insecurities, with 8 in 10 people eating less food than before [6].

India is an agrarian economy with an official farmer population of 100-150 million farmers [7]. The agriculture sector in India employs 263 million workers, of which $45 \%$ are cultivators and $55 \%$ work as agricultural labourers. The sudden imposition of the lockdown in India affected farming activities, leading to crops left unharvested in the fields, shortages of labour, delays in sowing the next crops, and shortages of agricultural inputs [8]. Farmers faced difficulties transporting their crops to markets and the Agricultural Produce Marketing Committees (APMC). A lack of storage facilities forced fruit and vegetable farmers to sell at extremely low prices [9]. In total, $42 \%$ of the export from India in MarchMay came to a complete halt because of the international travel and transport ban [10].

Kerala is a small state in the southern part of India. The state was touted across the country and also across the world for having dealt with the first wave of the pandemic much better than the rest of India, so that there was talk of a "Kerala model" [11]. A socioeconomic analysis has revealed that some factors such as land reforms, the promotion of education, and the early introduction of participatory governance through Panchayati Raj Institutions (PRIs) have provided the basis of the state's successful record in responding to the pandemic [12].

The net area sown is $53 \%$ of a total geographical area of 3,886,000 hectares in Kerala [13], and agriculture and allied sectors contribute to around $11 \%$ of the gross state value (GSV) [14]. The rural economy in Kerala is predominantly based on agriculture. People engaged in other occupations including retired people and people who have returned from working in the Gulf countries, also maintain farms in Kerala [15]. The major crop grown in Kerala is paddy or wet rice. Besides staple foods, Kerala is a major cultivator of spices. The most important spices cultivated are pepper, cardamom, cinnamon, clove, turmeric, nutmeg, and vanilla. Other important plantation crops are coconut, rubber, banana, and cashew. From the 1970s, there has been a gradual shift from subsistence crops to cash crops. Currently, nearly $63 \%$ of the total cropped area is allocated to cash crops. The average income of an agricultural household in Kerala is Rs. 11,888 (158 USD) compared to the national average of Rs. 6426 (86 USD).

Numerous actors from the civil society, the Food and Agriculture Organisation (FAO), and the World Food Programme (WFP) had raised concerns about the impacts of the pandemic on the livelihoods of low-income households and their food security [16]. The number of people in the world experiencing chronic hunger increased by up to 161 million more people in 2020, which was the single largest increase in decades. Although the pandemic started in December 2019, it still has and will continue to have effects on livelihoods, especially rural livelihoods.

Building farm resilience is extremely important for farms operating under the impacts of increasingly prevalent and unpredictable shocks [17]. At the farm level, resilience is understood as the ability of farms to adapt to climatic, social, and market-related shocks. Resilience can be improved through internal and external interventions and also by utilising farmer characteristics such as self-organisation [18] and innovative problem solving [19].

Adaptation strategies adopted by farmers are a function of their adaptive capacity [20]. Farmer adaptive capacity is a function of the ability to access, organise, or reorganise resources. It also depends on connections with organisations that influence their access to resources [21,22].

Previous studies related to agricultural production, livelihoods, and food security during the COVID-19 lockdown in India include those by Acharya in 2020 [23]; Azim Premji University in 2020 [24]; Harris et al. in 2020 [25]; Jaacks et al. in 2021 [26]; and Ceballos, Kannan, and Kramer in 2020 [27]. While Acharya (2020) studied the food security of poor households in the states of Bihar and Uttar Pradesh, the Azim Premji University (2020) looked at the impacts of COVID-19 pandemic on the livelihoods of farmers in the rural areas of 12 states in India (mostly North India), which did not include Kerala. Harris et al. (2020) used phone-based interviews to understand the problems that vegetable farmers in 
the four Indian states of Jharkhand, Uttar Pradesh, Karnataka, and Assam faced during the first lockdown of the COVID-19 pandemic. On the other hand, Jaacks et al. (2021) worked on providing baseline data about the impacts of the pandemic on agricultural production, livelihoods, and food security in 12 states of India (not including Kerala). Although some of these studies have focussed on farmers' livelihoods in particular states in India, there has been no study to date on the livelihoods of the farmers in Kerala. A few scientific studies have addressed the impacts of the pandemic on the farming sector in Kerala in general $[12,27]$. Other studies have focussed on the impacts of COVID-19 on particular farming sectors in the state, such as fisheries [28,29] and farm tourism [30]. However, so far only one study [31] has addressed a specific crop or farming system, i.e., a study on the market access and economic loss of paddy farmers in Kerala.

Our study aims to fill this research gap by focussing on three farming systems in Kerala as a case study. We hypothesise that the struggles faced by farmers during the pandemic as well as the strategies that farmers employ to secure their livelihoods are different depending on the crops they grow and on the farming systems they operate in. The farming systems chosen are coffee farming, Kole wetland rice farming, and homestead farming. These farming systems are representative of the state's agriculture in the sense that they cover cash crops and subsistence crops alike. With the aim of helping policymakers support agricultural households in India to effectively respond to this crisis, our study promotes a better understanding of the responses of farmer households to COVID-19 in the state of Kerala and of the factors that strengthen their resilience to the pandemic.

While the uncertainties that come along with the changing climate, especially in developing countries, will necessitate farming systems to be more resilient and to be easily adaptable and transformable [32], there is a dearth of studies on how farmers adapt their farming practices to conditions changing in unpredictable ways. It will be necessary in this context to analyse the transforming structures and processes through which these farming systems contribute to livelihoods and to identify the strengths of these structures and processes, as well as the weak points that need to be strengthened. Our study is intended to help formulate policies that would support farms facing unpredictable conditions. It will also help to fill a gap, as most studies dealing with farmer adaptation strategies pertain to climate change [33-35].

Institutional and biophysical constraints are external barriers to adaptation. Both short-term and long-term coping strategies can be employed by farmers dealing with a stress [17].

The main objective of our study is to analyse how resilient coffee farmers, Kole wetland rice farmers, and homestead farmers are in the face of uncertainty and thereby identify the strengths and weaknesses of the farming systems, as well as the farmers operating in them, in the context of the COVID-19 pandemic. The paper is structured around the following components:

1. Assess the impacts of the COVID-19 pandemic on farmers' livelihoods across the three farming systems;

2. Describe adaptation strategies of farmers in the three farming systems;

3. Assess the ability of famers to secure their livelihoods by analysing the resilience capacities and transforming structures and processes.

\section{Materials and Methods}

The data was collected from the state of Kerala in southern India (Figure 1). As per Koeppen's climate classification, Kerala has a tropical monsoon climate with excessive rainfall and high temperatures during the summer months [36]. Bound by latitudes $8^{\circ} \mathrm{N}$ and $13^{\circ} \mathrm{N}$ and longitudes $75^{\circ} \mathrm{E}$ and $77^{\circ} \mathrm{E}$, the state is divided into three sub-divisions: the lowlands consisting of the coastal plains, the midlands consisting of the undulating country east of the lowlands, and the forest-clad mountainous highlands on the extreme east. The temperatures in Kerala vary from $28{ }^{\circ} \mathrm{C}$ to $32{ }^{\circ} \mathrm{C}$ in the plains but drop to $20{ }^{\circ} \mathrm{C}$ in the highlands, with an average annual rainfall of $3055 \mathrm{~mm}$ over $12 \mathrm{months}$ in the state. 
Three farming systems were selected as case studies:

1. Coffee farming in Wayanad district;

2. Paddy farming in Kole wetlands of Thrissur and Malappuram districts;

3. Homestead farming in Thrissur district.

The case studies chosen are systems whose crops make up a significant portion of Kerala's agricultural economy. The coffee farming system also tells the story of a global pandemic impacting a small state through trade.

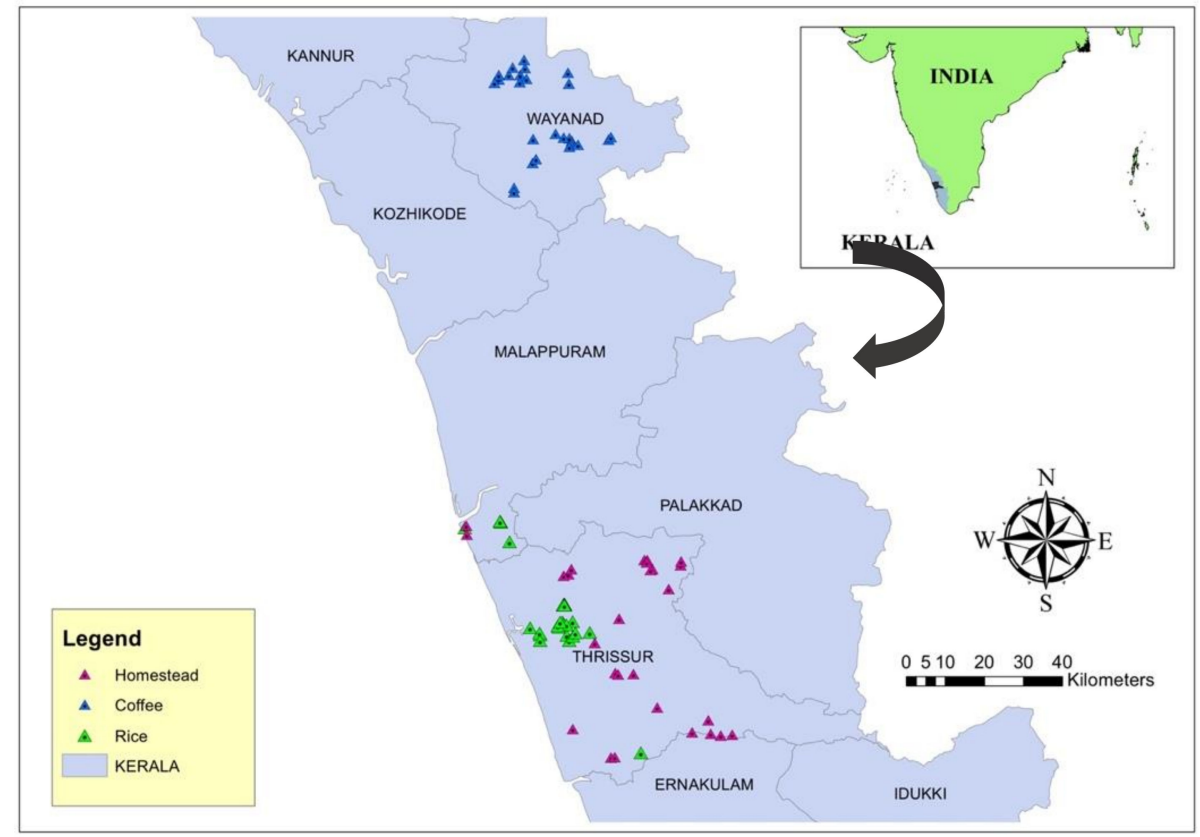

Figure 1. Locations of farmer interviews.

\subsection{Coffee Farming in Wayanad District}

Wayanad is a mountainous district in the Western Ghat mountain ranges of Kerala that has a cooler climate (average annual temperature $21.7^{\circ} \mathrm{C}$ ) compared to the plains of Kerala. One of the main crops grown in Wayanad is coffee. The coffee variant grown here is the Robusta coffee or Coffea canephora. Coffee in Wayanad is grown under shade trees. The most commonly planted shade tree species in Wayanad is silver oak or Grevillea robusta. In addition to the shade trees, most farmers cultivate one or two intercrops. The most common intercrops are areca nut (Areca catechu) and black pepper (Piper nigrum). Black pepper is trailed on trees such as Glyricidia sepium and Aphanamixis polystachya.

Coffee is one of the most important plantation crops in India. Amongst the coffee producing states of India, Kerala stands second and contributes around $21 \%$ of the national coffee production. Around $80 \%$ of Kerala's coffee production comes from Wayanad district [37]. For many years, farmers had been making an income from the intercrops (areca nut and pepper) additional to that from coffee. However, the yellow leaf disease, bud rot, and premature nut fall diseases of areca nut and the quick wilt disease of pepper, which have been spreading in Wayanad over the past years, have resulted in large-scale destruction of the two intercrops. Currently, the farmers rely mainly on coffee for their farming income.

The main market for the coffee beans produced in Wayanad is in Europe. India produces $2.5 \%$ of the global coffee output [38]. After Vietnam, India is the largest exporter of Robusta coffee in the world. India exports nearly $80 \%$ of the coffee produced [39]. As the domestic consumption of coffee remains stagnant in India, the global price determines the price of coffee in the country. Hence, an international crisis such as the pandemic has a strong influence on coffee prices, and thereby on coffee farmers' livelihoods. 


\subsection{Kole Wetland Rice Farming}

The Kole wetlands in the Thrissur and Malappuram districts in Kerala extend across 11,000 hectares between $10,020^{\prime}$ and $10,040^{\prime} \mathrm{N}$ latitudes and $75,058^{\prime}$ and $76,011^{\prime} \mathrm{E}$ longitudes, constituting an area of $136.4 \mathrm{~km}^{2}$. A major portion of these wetlands is submerged from June to November and lies 0.5 to $1 \mathrm{~m}$ below sea level. The Kole wetland consists of the floodplains of the Karuvannur and Kechery rivers, which empty into the Arabian Sea. During the monsoon season (June-August), the rivers discharge their floodwaters into these low-lying wetlands and raise the water level to more than three meters. The water is drained by farmers with the help of pumps in the months of October and November in order to enable rice farming. The rice crop is sown in December and harvested after 120 days in March. After dewatering, the bunds around the fields are raised and strengthened to prevent river water from seeping in and water in the fields from draining out [40].

The Kole wetlands are a multiple-use wetland ecosystem that fulfills hydrological, chemical, biological, and socioeconomic functions. The socioeconomic functions include the provision of productive agricultural areas, production of drinking water, and stocking of fish, among other activities. Rice and fish are the main products of the Kole wetlands of Thrissur and Malappuram, but rice is the most important crop. As floodplains, the wetlands are highly fertile and produce almost twice the yield of rice fields in Kerala [41].

In the Kole wetlands, rice is grown commercially. The entire Kole wetland in Kerala is owned by around 50,000 individual farmers organised into 150 farming societies called Padasekharams. Each Padasekharam is managed by joint-farming cooperative societies called PDS or Padasekhara Committees who jointly manage major operations.

After harvesting, rice grains are procured by Supplyco. Supplyco is an institutional mechanism in Kerala operated by the government to procure produce from farmers at a predetermined price.

\subsection{Homestead Farming}

Kerala has a long tradition of homestead farming. The term "homestead" is a local term used in Kerala and synonymous with the more widely used terms "home garden" or "tropical home garden" [42]. A mixture of both subsistence as well as commercial timber trees, fruit trees, spices, and vegetables are grown in the different strata of the homestead, varying from 5 to more than 40 species [43].

The main trees and crops grown in an average homestead in central Kerala are:

1. Timber trees: Teak (Tectona grandis), mahogany (Swietenia mahagoni), rosewood (Dalbergia latifolia), matti (Ailanthus excelsa);

2. Fruit trees: Mango (Mangifera indica), jackfruit (Artocarpus heterophyllus), cashew (Anacardium occidentale), jamun (Syzygium cumini), jambos (Syzygium jambos), banana (Musa spp.), bilimbi (Averrhoa bilimbi), guava (Psidium guajava);

3. Vegetables: Tomato (Solanum lycopersicum), bitter gourd (Momordica charantia), ash gourd (Benincasa hispida), ivy gourd (Coccinia grandis), snake gourd (Trichosanthes cucumerina), pumpkin (Cucurbita moschata), tapioca (Manihot esculenta), colocasia (Colocasia esculenta), dioscorea (Dioscorea esculenta), amorphophallus (Amorphophallus paeoniifolius);

4. Spices and condiments: Nutmeg (Myristica fragrans), green chilly (Capsicum annuum), curry leaves (Murraya koenigii), all spice (Pimenta dioica), cinnamon (Cinnamomum malabathram), black pepper (Piper nigrum), turmeric (Curcuma longa) [44].

Homesteads are managed mostly for subsistence, though some surplus is also sold commercially. Farmers with an intent to commercialise their homesteads concentrate on a few crops, such as coconut, areca nut, and banana, with perhaps some vegetables [45,46].

Different markets are used by the farmers for different crops [47]. Coconuts, areca nut, pepper, nutmeg, and other spices can be dried and stored until they are sold in the local market. Vegetables, however, are first used for household consumption and then sold if there is a surplus. Farmers who focus on vegetables are part of the VFPCK or the Vegetable 
and Fruit Promotion Council Keralam, which is an institution run by the Government of Kerala that helps them to effectively market their vegetables [48].

\subsection{Theoretical Framework}

The methodological framework used in this study is a combination of The Resilience Framework [49] and the Sustainable Livelihoods Framework [50] (Figure 2).

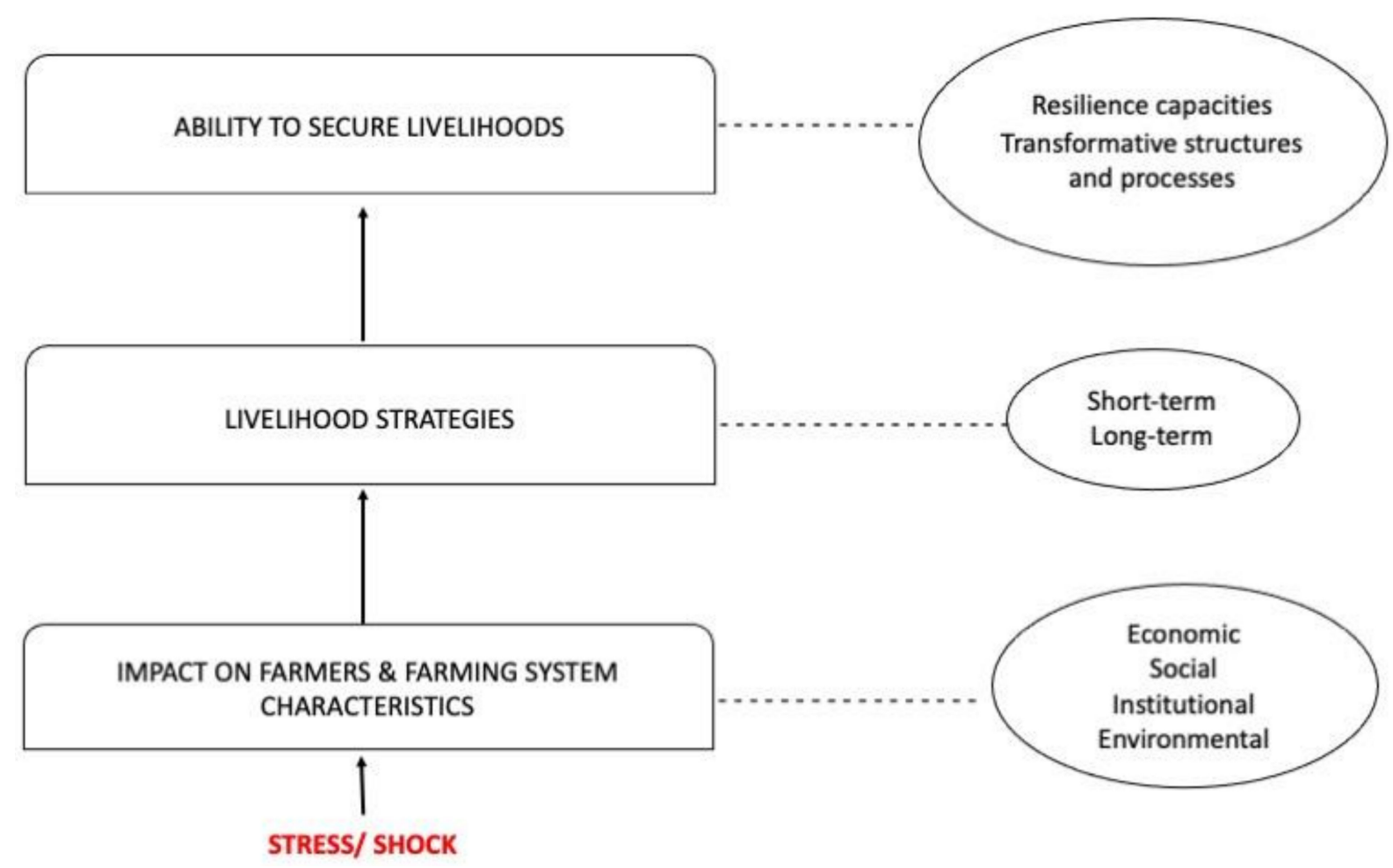

Figure 2. The framework used to study impacts, responses to shock, and ability to secure livelihoods (adapted from Levine 2014 and Meuwissen et al., 2019).

The Sustainable Livelihoods Approach proposed by Levine (2014) [50] was chosen to build the framework for the current study because it studies what people are trying to achieve and what strategies they employ to achieve their goals. It also attempts to understand the outcomes of these strategies. Levine's approach was derived, among others, from the Sustainable Livelihoods Framework of DFID (British Department for International Development) from 1999 [51]. This framework is drawn on to understand the transforming structures and processes that contribute to the ability of the different farming systems to secure livelihoods. The resilience framework [49] was chosen because it addresses the challenges to a farming system caused by the pandemic and because it also focusses on resilience capacities such as robustness, adaptability, and transformability, which can ensure the ability of livelihood strategies to secure livelihoods in the face of risks, shocks, and stresses.

Step 1: Studying the impacts of the pandemic on farmers and farming systems

When hit by a shock or stress, the impacts or challenges that impede the ability of the farming system to deliver the desired goods can broadly be divided into economic, environmental, social, and institutional impacts. These consist of shocks with reversible and irreversible effects on the farming system functions and of long-term stresses. Depending on the resilience of the system, shocks can have irreversible or only temporary effects on the farming system functions. An accumulation of stresses and shocks can increase the farming system's vulnerability in nonlinear ways, leading to tipping points when critical thresholds are crossed. 
To fulfil this objective, we focus our study on the shocks and stresses mentioned in the resilience framework by Meuwissen et al. in 2019.

Step 2: Understanding the livelihood strategies pursued by farmers and their adaptations

The activities undertaken by a household to provide a means of living are known as livelihood strategies. Especially in conflict and post-conflict situations, the livelihood strategies focus on security rather than economic gain [50]. In our case study, adaptation and livelihood strategies are used synonymously as the main strategies to secure livelihoods during the pandemic. In situations of risk and stress such as a pandemic, people do not judge their well-being solely in terms of their economic status but may give higher priority to personal security. Here, the framework defines "strategies" as a set of guiding principles by which people try to organise themselves to achieve their goals (or return to normalcy and cope with the new situations created by the pandemic), in order to understand what people had intended to do and why, and what they actually did and why. The strategies are also influenced by people's perceptions both of the options available and of themselves and their capacities.

This step was derived from step 1 of the Sustainable Livelihoods Framework by Levine, who explained that the first step to understanding livelihoods is to understand "what people are doing".

Step 3: Assessing the resilience capacities and factors that enable adaptation strategies to secure livelihoods

The resilience of farming systems is defined as the ability of a farming system to ensure the provision of the system functions in the face of increasingly complex and accumulating economic, social, and institutional shocks and stresses. Within the framework, resilience capacity is divided into three capacities, i.e., robustness, adaptability, and transformability [49]. Robustness is the capacity of a farming system to withstand stresses and anticipated or unanticipated shocks. Adaptability is the capacity to change the composition of inputs, production, marketing, and risk management in response to shocks and stresses without changing the structures and feedback mechanisms of the farming system. Transformability is the capacity to significantly change the internal structure and feedback mechanisms and functions of the farming system in response to either severe shocks or enduring stress. The resilience capacities used in the study were derived from the resilience framework proposed by Meuwissen et al. in 2019.

There are factors associated with every farming system and farmer characteristics that enhance or constrain these resilience capacities. These are the transforming structures and processes and were derived from the Sustainable Livelihoods Framework proposed by DFID [51].

\subsection{Data Collection and Analysis}

In our study, the resilience capacities and their underlying factors were studied by questioning farmers and by analysing farming systems. Robustness was studied through questions pertaining to the ownership of land and the continuity of farming activity. Adaptability was studied by analysing farmers' and farming system's ability to change without changing the feedback and structure of the system. Transformability was studied by asking questions regarding permanent changes made within the farm and the feasibility of these changes within the context of the pandemic. The "story behind the performance", for example, of why a function does not recover after a shock and why some functions decline gradually while others are maintained or enhanced was expected to be understood through additional interview questions and is explained in the discussion chapter. By way of this analysis, we expected to gain more contextualised and nuanced insights into the resilience capacities of the selected farming systems in the face of shocks.

The data were collected from 90 farmers whose primary livelihood was farming, with 30 farmers in each of the three farming systems. As the study aimed to also understand how the impacts of the first wave of the pandemic varied across farmers that cultivated 
different crops, as well as the same crop in different ways, we collected information from farmers engaging in organic and non-organic rice cultivation from the Adat panchayat in Thrissur, and from organic and non-organic coffee growers in Wayanad.

Snowball sampling was the main technique used to identify sources. Key informants and sources were identified in each category across different areas in central Kerala by contacting professors and officers working in the Kerala Agricultural University, and also by collecting contact numbers from acquaintances. In each category, an attempt was made to keep the sample as representative as possible by choosing contacts from at least a few different places where the respective farming systems are practiced and then snowballing from them. Contact data for some farmers were collected directly from the Kerala Agricultural University and the Department of Agriculture, Kerala, which are the principal bodies of Kerala state for the sustainable development of its agriculture.

Comprehensive interviews with farmers had to be conducted via phone calls with the help of a semi-structured questionnaire template due to COVID-19 travel regulations. The questionnaire template was crafted on the basis of the Resilience Framework by Meuwissen et al. and the Livelihoods Framework by Levine by including questions referring to the different impacts of the pandemic on the farmers, the kinds of adaptation strategies used, as well as the resilience capacities and transforming structures and processes (Annex 1). The phone interviews were recorded, translated, and transcribed manually. The interviewees were asked for their consent to record the interviews. Experts in the respective fields were also contacted to supplement interview data with background data and official information.

We collected both quantitative and qualitative data. The comprehensive interviews with experts and farmers were analysed using qualitative analysis software (Atlas.ti 9.1.1). Code groups were made based on the formulated research questions, i.e., the impacts of the pandemic, responses of the farmers, and the ability of farmers to secure their livelihoods. These code groups were sub-divided into the types of impacts, short-term and long-term responses, resilience capacities, and transforming processes and structures. Statements from the interview transcripts were grouped into these code groups and coded in order to organise and elucidate information to answer the research questions.

As data collection was performed remotely through phone interviews, we felt that some farmers were not comfortable and that more information could have been gained had the interviews been performed face to face. Additionally, focus group discussions could not be conducted as planned because of travel restrictions and because of the difficulty of conducting such discussions remotely.

The homestead category is problematic as it includes a wide and diverse range of farmers. According to John 2014 [42], the home gardens in Kerala vary with respect to the number of residents, to the land allocated for cultivation, and to wealth and income generation to such an extent that this category consists effectively of land use types which differ from each other in various ways, e.g., with respect to economic goals. In some cases the income generated from homesteads is enough to meet the household consumption demands [43,45], in others it helps to supplement income, and for others still it helps families to reduce or avoid purchases [42].

\section{Results}

On the basis of the interviews that we had conducted, we prepared a demographic profile of the respondents, assessed the impacts of the pandemic on the different farming systems and the responses of farmers to these impacts, and analysed the ability of farmers to secure their livelihoods under the conditions of the pandemic.

Out of the surveyed farmers, $92 \%$ were male and $8 \%$ percent female, while $68 \%$ of the surveyed farmers were above the age of 53 . The majority of farmers had been to at least higher secondary school or university or had other vocational training $(56 \%)$, and all of the farmers had at least attended primary school. Furthermore, $78 \%$ of the farmers had more than 10 years of experience in farming. 


\subsection{Impacts of COVID-19 on Farmers}

$70 \%$ of farmers reported that the pandemic had impacted their farming practice in some way, while $30 \%$ of the farmers thought that the farming sector was relatively unaffected by the pandemic.

The impacts of the pandemic on the farmers we studied (Table 1) can broadly be divided into economic impacts, social impacts, and institutional impacts.

Table 1. Impacts of the COVID-19 pandemic on farming systems.

\begin{tabular}{|c|c|c|c|c|}
\hline & Impacts & $\begin{array}{l}\text { Coffee } \\
\text { Farming }\end{array}$ & $\begin{array}{l}\text { Kole Wetland Rice } \\
\text { Farming }\end{array}$ & $\begin{array}{l}\text { Homestead } \\
\text { Farming }\end{array}$ \\
\hline \multirow{6}{*}{ Economic } & - Price drops for outputs & $x$ & $x$ & $x$ \\
\hline & - New competition in markets & & & $X$ \\
\hline & - Increased cost of hired labour & $X$ & $x$ & $X$ \\
\hline & - Scarcity of farm inputs & $X$ & $X$ & \\
\hline & - Reduced food and income security & $X$ & & \\
\hline & - Surplus produce & & & $\mathrm{X}$ \\
\hline \multirow{2}{*}{ Social } & - Insufficient availability of seasonal labour & $x$ & $x$ & \\
\hline & - Lack of physical farmer interactions & & $x$ & $x$ \\
\hline \multirow{5}{*}{ Institutional } & - Transport bans & $X$ & $X$ & $X$ \\
\hline & - Sudden change in access to markets & & & $x$ \\
\hline & - Working regulations & $X$ & $x$ & $x$ \\
\hline & - International instability & $X$ & & \\
\hline & - International market search & & $x$ & \\
\hline
\end{tabular}

\subsection{Economic Impacts}

The economic impacts common to all three farming systems were the increase in the cost of labour and decrease in prices for agricultural products. The three farming systems, however, also faced economic impacts that affected only one or two of them (Table 1).

\subsubsection{Economic Impacts on Coffee Farming}

The economic impacts of the pandemic on coffee farming were the increase in cost of labour, price drops of coffee beans, scarcity of farming inputs, and reduced food and income security.

The cost of labour has been increasing in Kerala over the past decades and the pandemic caused it to rise even further. The labour charge currently is Rs. 750-800 ( 10-11 USD) for a male labourer and Rs. 550-600 ( 7-8 USD) for a female labourer in Kerala. The majority of labourers employed in coffee farms are from indigenous groups from Wayanad (71\%). They live either in their indigenous settlements (kudi) or are housed on or near the coffee estate. The labour charge per person reported by one farmer that we had interviewed was Rs. 500-550 ( 6-7 USD), including money for expenses and food. Labour charges increased during the pandemic, although only by a fraction according to one respondent. Smallholder farmers tried to get by without labourers, as the labour charge was reportedly too high for them. One coffee farmer mentioned, "Generally, now in Wayanad, people that do farming with labourers for coffee farming are very few. Because of the high labour charges and other input costs, we end up not getting a good income from coffee farming". In total, $20.8 \%$ of coffee growers do not employ labourers or employ labourers only for some special operations. Only $8 \%$ of the growers employ migrant labourers from other states.

Global price fluctuations for coffee after the pandemic translated into a decrease in the local price of coffee in Kerala from Rs. 70-80 ( 1 USD) per $\mathrm{kg}$ in the year before the pandemic to a price of Rs. 60-65 ( 0.81 USD) per kg after the pandemic [52]. One coffee farmer said, "Of course there was a slight decrease, a 10-20\% decrease in prices. It picked up again after 2-3 months. There were news reports that all the coffee shops have shut, people are not moving around, and so coffee prices will crash. And actually, it did not crash to that extent. The actual price crash is happening now (March 2021)". 
The pandemic also affected farming inputs. An officer working in the coffee board mentioned that subsidised irrigation equipment for coffee farmers in Wayanad could not be delivered due to the lockdown, so that farmers had to rely on the blossom showers in February and experienced a reduction in yield. Two farmers mentioned that they had trouble procuring the fertilisers for the coffee trees on time because of the lockdown and that, as a consequence, the quality of their coffee beans had deteriorated.

Smallholder coffee farmers especially experienced a reduction in food and income security this past year because of the low prices they got for their coffee crops. Some respondents surmised that this was because of the low return on investment for coffee. "The input charges such as fertilisers, labour charges, and maintenance charges are very high in Kerala now compared to the price we get for $1 \mathrm{~kg}$ of coffee. This is increasing year after year and the problem was only aggravated during corona." One farmer mentioned that he survived only because food security was provided by the government during the pandemic, "otherwise, there would have been starvation deaths here (in Wayanad)".

\subsubsection{Economic Impacts on Kole Wetland Rice Farming}

The economic impacts of the pandemic on Kole wetland rice farming included an increase in the cost of labour, price drops for organic rice, as well as increasing costs of inputs and lower level of inputs.

In the Kole wetlands, the situation was different between farmers who grow organic rice and farmers who grow conventional non-organic rice. In the case of conventional rice, the state government of Kerala procures the rice directly from the farmers via the agency Supplyco. The base price of this rice went up from Rs. 26.95 per $\mathrm{kg}$ (0.36 USD) in the year 2020 to Rs. 27.48 (0.37 USD) per kg in 2021. Organic farmers, on the other hand, suffered from low prices. As there is no base price for organic rice, farmers have to sell in private markets. When farmers started organic farming, they received around Rs. 52 per $\mathrm{kg}$ (0.69 USD). However, after the lockdown, they had to reduce the prices to Rs. 35 per $\mathrm{kg}$ (0.47 USD) in 2020 and Rs. 48 per kg (0.64 USD) in 2021.

In Kole wetland rice farming, most operations are performed by migrant labourers. During the lockdown, some migrant labourers returned home while others stayed back in Kerala and demanded a wage increase to Rs. 850-900 ( 11-12 USD) per day. In some cases, they also demanded a change of daily wage to contract-based labour. In other cases, farmers replaced the migrant labourers who had left for their homes with local labourers, who are more expensive than migrant labour. A Kole wetland rice farmer mentioned, "Usually to plant one acre, Rs. 4000-4200 ( 53-56 USD) is given to a contractor who delegates the work to migrant labourers. This time, I spent Rs. 9000 (121 USD) to plant one acre using local female labourers." Another farmer said, "I tried to reduce my dependence on farm labour after the pandemic by doing most of the farm operations myself. This year, I was able to get by with employing no labour at all". A third farmer mentioned, "I got the same amount of profit as the previous year as I was able to cut short some expenses like labour because of COVID."

Another economic impact of the pandemic on Kole farmers was that some farmers could not procure inputs such as seeds and fertilisers on time. One farmer reported that the price for fertiliser had increased from the earlier price by Rs. 250 (3.33 USD) for one sack, which he could no longer afford during the lockdown.

\subsubsection{Economic Impacts on Homestead Farming}

The economic impacts on homestead farming included an increase in the cost of labour, a reduction in prices, new competition in markets, surplus produce, and an expanded market base.

In total, $40 \%$ of homestead farmers mentioned that they faced the problem of increasing labour costs after the pandemic started. One farmer said, "In my farm, $80 \%$ of the work is done by my wife and me. Rs. 800 (10.74 USD) is the daily wage for labourers here now. For 
the time that we work in the fields every day, I would need to pay 2 people, i.e., spend Rs. 1600 (21.47 USD) for that work. Then my farm would not be profitable at all."

In total, $56 \%$ of the homestead farmers surveyed reported that they received an extremely low price for the annual crops they cultivated. While it is normal for the prices of perennial crops such as coconut, areca nut, pepper, and nutmeg to fluctuate within and between years, the prices of annual crops such as vegetables declined sharply after the imposition of the lockdown (Table 2). While the produce from perennial trees can be dried and stored to sell when prices are better, this is not the case for perishable produce from annual crops. Crops such as nendran banana and tapioca saw reductions of more than half of their normal prices. The farmers reported that this was because of the low demand as people started growing their own produce at home. One farmer also mentioned that he felt that banana had such a low price because of the difficulties in exporting the crop due to the lockdown, "Maybe our bananas are not being exported. But when usual export happens, local shortages will happen, so demand increases and price increases for us."

Table 2. Prices changes for crops cultivated in a homestead farm after COVID-19 (data from VFPCK, Kerala [53]).

\begin{tabular}{ccc}
\hline Crop & $\begin{array}{c}\text { Price per kg before } \\
\text { COVID-19 in Rs. (USD) }\end{array}$ & $\begin{array}{c}\text { Price per kg after COVID-19 } \\
\text { in Rs. (USD) }\end{array}$ \\
\hline Nendran banana & $40-50(0.53-0.67)$ & $20(0.27)$ \\
\hline Kadali banana & $75-100(1-1.33)$ & $40-45(0.53-0.6)$ \\
\hline Palayankodan banana & $20-25(0.27-0.33)$ & $2-3(0.027-0.04)$ \\
\hline Turmeric & $70(0.93)$ & $15(0.2)$ \\
\hline Tapioca & $18-20(0.24-0.27)$ & $6-8(0.08-0.11)$ \\
\hline Snap melon & $40-45(0.53-0.6)$ & $5(0.067)$ \\
\hline Yard long beans & $40-45(0.53-0.6)$ & $25(0.33)$ \\
\hline Ivy gourd & $15-30(0.2-0.4)$ & $5(0.067)$ \\
\hline Snake gourd & $18-30(0.24-0.4)$ & $5(0.067)$ \\
\hline
\end{tabular}

There has been an increased interest among rural and urban people of Kerala to engage in agriculture. In total, 4 of the 30 farmers surveyed in the homestead category felt that employees who had started growing their own vegetables because they were working from home with more leisure for such activities were a threat to their farming income. However, one farmer mentioned that "this is a short-term change. Once they go back to work in the city, it will be just us, the farmers in the market again".

A grave problem faced by homestead farmers was surplus produce during the lockdown. Here, $48 \%$ of the farmers reported that they had surplus produce that they could not sell during the lockdown. Farmers reported difficulties in selling turmeric, bananas, amaranth, beans, ivy gourd, snake gourd, bitter gourd, and chilies. "Sometimes, we did not even want to harvest the crop from the fields. If it decays in the field, it would at least be good for the soil".

\subsection{Social Impacts}

Social impacts of the pandemic included labour shortages and a lack of social interactions. There were no common social impacts found across the systems and only specific impacts for each system.

\subsubsection{Social Impacts on Coffee Farming}

The main social impact on coffee farming was the shortage of labour. The $8 \%$ of coffee growers that used migrant labourers did not face this problem, as the lockdown had started after the harvest. Employers of local labourers (except those that housed the labourers on 
or near the estate), however, faced difficulties in getting labourers to their farms, as they usually came from places far away from the estates.

\subsubsection{Social Impacts on Kole Wetland Rice Farming}

The social impacts of the pandemic on Kole wetland rice farming included insufficient seasonal labour and a lack of physical farmer interactions and discussions.

In total, $89 \%$ of Kole rice farmers use migrant labour for all operations in their rice fields. When the lockdown was announced in March 2021, a reverse migration took place that saw the majority of the migrant labourers returning to their homes in the north of India. This created a severe scarcity of labour in Kerala which affected only some farmers as the harvesting had already been completed on most farms. However, labour scarcity persisted into the next cropping season (December 2021), as most of the migrant labourers who had returned home did not come back to Kerala. A farmer mentioned that normally he harvested 7-8 tonnes of paddy per hectare. With labour shortage, he obtained a yield of only 3-4 tonnes per hectare.

Group gatherings were prohibited during the pandemic. Hence, the usual meetings with the PDS (Padasekhara Committees) could not be conducted. Some of the meetings were instead performed online. A rice farmer had mentioned, "all the usual meetings we usually had physically were transferred online. This has led to lack of physical contact and intimacy with friends." Another farmer also mentioned that some of the administrative work had been transferred online, for instance filling out forms for subsidies, which was easier for farmers as they did not have to travel to the agricultural offices. "We also had to reduce farmers' direct contact with each other. Now we only do phone contact. Before the pandemic, many farmers would meet in the fields in the morning and have many farmers meetings where we used to discuss our problems. But now we don't have much of a relationship. It's still going on the same way even now. We do the work on our own farm and then come directly back home".

\subsubsection{Social Impacts on Homestead Farming}

In total, $35 \%$ of farmers in the homestead belong to a local farmers organisation or a cooperative. Due to the suspension of the regular meetings that they usually had, during the lockdown, and even after the lockdown was lifted, they have not been able to meet and discuss their issues. Here, $18 \%$ of these farmers mentioned that they missed the regular meetings and that it was difficult to know what was going on because of the decrease in interactions between farmers.

\subsection{Institutional Impacts}

The common institutional impacts on all three farming systems were the bans on transport, mobility restrictions, and the working regulations.

\subsubsection{Institutional Impacts on Coffee Farming}

The institutional impacts of the lockdown on coffee farming were transport delays, instability of international markets, and difficulties in working on the farm.

The mobility problem in coffee farming affected mainly labourers who found it difficult to reach the estates. Since public buses, which are the usual mode of transport, were halted, labourers were without work for almost two months and farm operations were delayed.

$10 \%$ of coffee farmers had a problem when one or some labourers got infected with the coronavirus and farming operations had to stop until all the labourers were through with quarantining.

Coffee farming was also affected by the instability of the international coffee market. As the domestic consumption of coffee remains more or less the same in India, the price of coffee in India is determined by international prices. Italy is the largest consumer of the Robusta coffee produced in India, importing around 65,000 tons of Indian Robusta coffee every year. After the COVID-19 pandemic began, international coffee prices experienced 
high volatility. Prices for coffee were low because "export is slow due to corona", according to one farmer.

\subsubsection{Institutional Impacts on Kole Wetland Rice Farming}

The institutional impacts on Kole wetland rice farming involved a change in market access for organic rice growers and a search for international markets.

In the Kole wetland rice farming system, transport was the main problem for conventional rice growers. However, this lasted only two weeks until government interventions took place. The government interventions did not apply to organic farmers who wanted to sell in private markets to get better prices for their crops. Their identified markets were cities in the North of India, meaning they could not transport their produce because of the mobility restrictions.

Organic Kole wetland farmers were curious to know whether their brand of rice could be sold outside of India. Two of the seven organic farmers we interviewed asked us if we knew of any importers of organic rice. Since the purchasing power of people was reduced after the pandemic, they no longer saw a market for their product in India.

Before the COVID-19 pandemic, a small private cooperative bank was procuring organic rice from farmers in Thrissur. After the pandemic, however, the bank was no longer willing to do so because people were no longer interested in buying organic rice. Other targeted markets for the organic rice farmers were in big cities such as Delhi, Hyderabad, and Mumbai. However, the farmers could not access these markets as the rice could not be transported further north in India because of the lockdown.

\subsubsection{Institutional Impacts on Homestead Farming}

The institutional impact on homestead farming comprised transportation problems and changes in market access.

In the homestead category, $4 \%$ of the farmers could not transport their produce due to the lockdown. One farmer selling mangos mentioned that the market for his mangos is in the north of India. Due to the nationwide lockdown and ban on transport, he had to sell his mangos in the local market for half the price that he normally gets.

In total, $78 \%$ of the farmers experienced a change in the markets they usually have access to. There are different markets for the different crops grown in a homestead. Farmers would sell crops either through a seller they have personal connections with or through the Vegetable and Fruit Promotion Council Keralam (VFPCK), which remained open after the initial stages of the lockdown. Open markets where vegetables and crops are usually sold were closed during the entire lockdown to avoid the gathering of crowds. Hence, farmers who used to sell their produce in these markets had to look for alternative outlets. One farmer said, "My normal market had been disrupted because of COVID. I usually sold my vegetables to prepare the mid-day meal at schools for the Mid-Day Meal Scheme (MDMS). When schools closed, I lost this market." Another farmer mentioned that the lack of weddings and other functions after the pandemic impacted his vegetables business.

\subsection{Livelihood Strategies}

Farmers have responded with a number of strategies to the various impacts caused by the pandemic. Some of these strategies are short-term responses, while others are for the long term and likely to persist after the lockdown and pandemic are over. On the other hand, $12 \%$ of coffee farmers, $52 \%$ of Kole wetland rice farmers, and $25 \%$ of homestead farmers mentioned that there was no need to fundamentally change their farming system or farming method due to the pandemic.

The responses and strategies varied across the three farming systems (Table 3). 
Table 3. Types of responses in different farming systems to the impacts of the pandemic.

\begin{tabular}{|c|c|c|c|}
\hline Responses & Coffee Farming & Kole Wetland Rice Farming & Homestead Farming \\
\hline Short-term responses & $\begin{array}{l}\text { - } \quad \text { Online farmer help groups } \\
\text { - } \quad \text { Increase in crop storage to } \\
\text { wait for better prices }\end{array}$ & $\begin{array}{l}\text { - Using local labour force at } \\
\text { higher cost } \\
\text { - Change in planting method } \\
\text { from planting rice seedlings to } \\
\text { direct sowing of seeds }\end{array}$ & 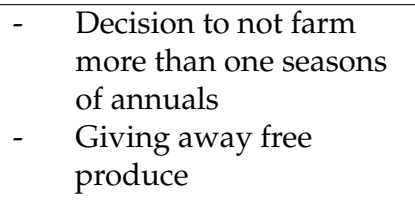 \\
\hline Long-term responses & $\begin{array}{ll}\text { - } & \text { Increase in livestock } \\
\text { - } & \text { Agmponents of farm } \\
\text { - } & \text { Reducing and replacing } \\
\text { annuals } \\
\text { - } & \text { Increase in non-farm income }\end{array}$ & $\begin{array}{ll}\text { - } & \text { More digital technology in } \\
\text { farming } \\
\text { - }\end{array}$ & $\begin{array}{ll}\text { - } & \text { Using digital solutions } \\
\text { to sell } \\
\text { - } \quad \text { Bring land under paddy } \\
\text { cultivation } \\
\text { - } \quad \text { Selling directly from } \\
\text { their houses } \\
\text { - } \quad \text { Value-addition }\end{array}$ \\
\hline
\end{tabular}

\subsubsection{Short-Term Strategies}

Short-term strategies differed between the three farming systems studied. There were no strategies common to the three systems, only strategies that were specific to each one of the three systems.

\section{Short-Term Strategies of Coffee Farmers}

The short-term strategies of coffee farmers involved joining online farmer help groups and increasing storage of the coffee crop in expectation of increasing coffee prices.

In the Meenangadi locality, a coffee board officer had formed a social media group for all coffee farmers in the area. Coffee farmers, irrespective of their land holding size, social status, or occupation, are active participants in this group, along with a few agricultural officers who give scientific advice. They discuss crop improvements, new interventions and ideas, subsidies, and anything related to coffee growing in the group. This group has helped with strategizing many responses against the pandemic said $7 \%$ of the coffee farmers interviewed.

In total, $31 \%$ of coffee farmers decided to store their beans and wait for a better price. Of these, $58 \%$ were large growers, which meant they had access to storage facilities. Smallholder farmers resorted to using group storage measures to stock the beans. A coffee farmer mentioned, "The biggest problem is that if we store the coffee, the weight reduces. Hence, long-term storage is not possible. Storage also requires a lot of space. For smallholder farmers, nobody has that kind of space. We dry it and try to sell it off usually."

\section{Short-Term Strategies of Kole Wetland Rice Farmers}

The short-term strategies of Kole wetland rice farmers included using local labour at higher cost and a change in planting method from planting rice seedlings to direct sowing of seeds.

Responding to the labour shortage in the state after the pandemic, the Kole wetland rice farmers resorted to bringing in local people and labourers from other places to work on their fields. One farmer mentioned that local boys started working in the farms. A farmer also brought some migrant labourers back to Kerala through an agent in West Bengal in Eastern India. Some farmers brought in labourers from the neighbouring state of Tamil Nadu. There were two large-scale rice farmers who also flew in migrant labourers to Kerala from northern India during the sowing season, provided food and shelter for them during the quarantine, and then provided them employment. Bringing in labourers from other places requires finances. The Kole farmers could do this because farming in the Kole wetland is performed in groups that have a collective fund for such operations.

In total, $47 \%$ of the Kole rice farmers had changed their planting method. Traditional rice is planted using two methods in Kerala-one is direct sowing (veda), where the seeds are scattered onto the field, while the other method is to sow the seeds into seed beds and 
allow them to grow to seedlings, which are then manually transplanted onto the fields in rows (naadu).

In the Kole wetlands of Thrissur and Malappuram in Kerala, the planting method (naadu) had been used for many years. This method shows more promise, as there are fewer weeds. However, the pandemic prompted a sharp decline in labour in the state, which made the farmers change to the direct sowing or veda method. This strategy also shows promise to turn into a long-term strategy for some farmers, as they discovered that it was much more profitable to perform direct sowing. One farmer said, "We would continue with sowing or planting depending on the availability of labour in the next season."

\section{Short-Term Strategies of Homestead Farmers}

The short-term strategies used by homestead farmers included decisions to discontinue growing annual crops until the prices improved and to give away free produce.

In total, $10 \%$ of the homestead farmers decided to grow annual crops that had low prices in the past year for not more than one season, as they were not hopeful that the pandemic would soon be over. Hence, schools would remain closed and there would be no weddings or functions where they could receive bulk orders. They said that "it was painful to throw away the crops that we farmed last year. I do not want to repeat the same this year as well".

Two farmers, on the other hand, were planning to increase the production of crops that had low prices this year, anticipating that if many farmers would discontinue cultivating these crops, they would get a high price in coming seasons.

As a major part of the surplus produce in homestead farms that could not be sold during the pandemic was perishable, some farmers resorted to giving away their produce for no charge. Here, $10 \%$ reported that they either threw the produce away or did not harvest the crop. One farmer gave their vegetables to the community kitchen free of cost, while others donated their harvest to the panchayat (local governing body) or to an old age home. Two farmers mentioned that they fed the vegetables to their cattle in order to not let them rot.

\subsubsection{Long-Term Strategies}

A common long-term strategy is to use more digital technology to make farming and marketing more efficient. Here, $14 \%$ of farmers from all categories reported using digital technology for farming after the pandemic began. By using WhatsApp and other social media platforms, homestead farmers were able sell some of the crops they had grown. They were mostly sold to nearby households and previously frequented contacts.

\section{Long-Term Strategies of Coffee Farmers}

The long-term strategies of coffee farmers included an increase in organic coffee production, an increase in the use of fertilisers to enhance coffee production, an increase in livestock components on farms, the reduction and replacement of annual intercropping, and attempts to increase non-farm income.

$45 \%$ of the conventional coffee farmers we interviewed mentioned that they were also engaged in organic coffee farming, while $6 \%$ of the farmers had decided to dedicate more of their estate area to organic coffee after the pandemic. Cultivating organic coffee is slowly gaining preference over cultivating non-organic coffee. A reason could be that the company whom they sell the organic coffee beans to gives a higher price (0.067-0.13 USD extra per kilogram) for organic coffee compared to the open market price for regular coffee at a particular time. However, the payment is given to the farmers much later than on the open market. Smallholders sell their beans mostly in the open market to receive immediate payment, and only those farmers that have storage facilities and can wait for delayed payment if they sell to the organic society engage in organic farming.

As the productivity of intercrops used in coffee farming (pepper and arecanut) is decreasing, coffee farmers have been trying to step up the production of coffee in order 
to increase their livelihood and security. One farmer said that he wanted to increase his output from 100 sacks of coffee beans that he currently collects to 120-130 sacks. He will do this by applying more chemical fertilisers. Another farmer said, "We are trying to increase the production of coffee. There is nothing else we can actually do. In our weather conditions, we get 20 bags ( 1 bag is $54 \mathrm{~kg}$ ) from one acre of land. We are trying to increase the production to 30-35 bags, with maximum manuring, fertilising, and maintenance. When the production increases, the money we could earn would also increase".

Most farmers in Wayanad are buying livestock to obtain a more stable income. "The future of farming in Wayanad is through dairy farming", said one coffee farmer. 9 out of 30 farmers said they had started dairy farming recently. They had one or two cows, and goats whose milk and meat they used to supplement their agricultural income. "The only way to sustain farming in Wayanad is through the dairy sector now. All the other crops are dying".

To supplement the farming income from coffee, coffee growers (especially smallholder farmers) grow intercrops such as banana, tapioca, yam, and turmeric on their coffee farms. As these intercrops have not been profitable over the past two years, coffee farmers reduce efforts for the production of intercrops such as yam and turmeric and replace some crops such as banana with other intercrop options.

Although farming was their primary livelihood, $43.4 \%$ of the coffee farmers we surveyed had jobs other than farming. Most mentioned that it was difficult to get by with just coffee farming unless a farmer had large land holdings. 3 of 30 farmers started working outside of the farming sector as a strategy to obtain a more stable income than coffee farming would provide. One farmer mentioned, "It is only because I started an insurance company on the side that I can survive".

\section{Long-Term Strategies of Kole Wetland Rice Farmers}

The long-term strategies of Kole wetland rice farmers included expansion of the land under rice cultivation, a decrease in organic rice cultivation, and an increase in mechanisation.

The area under rice cultivation had been declining steadily until the year 2010-2011 in Kerala. However, cultivating rice has suddenly come to be regarded a remunerative enterprise for farmers in Kerala. Rice farming was reported as being the most profitable crop in Kerala by 27 of the 30 farmers interviewed in this category. "There is adequate government support for the growing and marketing of rice in Kerala at the moment.", said one farmer. Farmers are being offered a minimum support price of Rs. 2650 (35.30 USD) per quintal, which increased from Rs. 2630 (35.03 USD) in the past year. The government-aided organisation Supplyco also collects the rice directly from the farmers' fields and processes it. Moreover, there are subsidies in place for inputs such as fertilisers and machines, which are provided by the government. Additionally, farming fallow land for rice is currently encouraged by the government. Whether on Kole rice wetlands or other land, rice farming is gaining prominence in Kerala.

As organic rice is not procured by the state government in the way conventional rice is and because the price of the organic rice is slightly higher than that of normal rice, organic farmers usually have trouble finding buyers. As there were no means of transport to send the rice to markets in other states and because the private cooperative bank that usually procured the organic rice was delaying the procurement after the onset of the pandemic, the farmers had to store massive quantities of rice in storage warehouses. Since a warehouse facility is not available near their farms, they were forced to transport the rice to the nearby district of Palakkad $70 \mathrm{~km}$ away during the lockdown, where the warehouse facility cost Rs. 3000 (39.96 USD) per day. Some farmers mentioned that they consumed their rice themselves as they did not believe it would get sold. Finally, the private cooperative bank procured the rice but at a very low price. Hence, they had to incur a huge loss this year as well. 
To let the public and other officials know about their situation, a group of farmers published an article in the newspaper conveying the message that they would stop organic farming next year since it was no longer profitable for them. "When farmers are doing conventional rice farming and getting Rs. 40-50,000 (532-665 USD) worth of profits, organic growers get only 17-20,000 (226-266 USD)." Another farmer pointed out, "What is the point of trying to make the health of other people better by cultivating organic rice if our own needs cannot be met. Hence, from the next season onwards, we have decided to go back to conventional rice farming".

Machines were used on $68 \%$ of the rice farms for planting due to the shortage of migrant labourers this year. The machines were loaned from the agricultural department. One farmer said, "Using machines is very profitable. It costs only Rs. 1000 (13.32 USD) to harvest rice from 1 acre of land".

\section{Long-Term Strategies of Homestead Farmers}

The long-term strategies of homestead farmers include starting or expanding paddy cultivation, adding value to their produce, and selling produce directly from their houses.

$16 \%$ of the farmers from the homestead category mentioned that they were going to start rice farming or expand the area under rice. Because of the reasons mentioned in the section about the long-term strategies of Kole wetland rice farmers, these farmers believe that rice is the most stable and profitable crop in Kerala at this time.

Some farmers in the homestead category said that they decided to process their produce during the lockdown. In total, $6 \%$ of the farmers in this category said that they would do so only after the pandemic. Some decided to convert their produce into jams, preserves, and juices. Doing this, they could earn more revenue as well as prevent the surplus produce from being wasted.

$40 \%$ of the farmers surveyed reported that they started to sell their produce from home after the pandemic began. This was done in response to not being able to transport their crops, as well as to the lack of access to open markets. Two farmers mentioned that they started to grow crops on demand by customers. They expected to continue this service even after the pandemic ends.

\subsection{Ability to Secure Livelihoods}

The ability to secure livelihoods is closely related to the resilience of the farming system. The resilience of farmers and farming systems is measured with the help of the three resilience capacities of robustness, adaptability, and transformability. Resilience is enhanced or constrained by transformative structures and processes such as levels of government, the private sector, laws, policies, culture, and institutions.

\subsubsection{Robustness}

The common factors contributing to high or low robustness of the three studied farming systems include ownership and continuity of farming.

\section{Robustness of Coffee Farmers}

The robustness of coffee farmers is influenced by the migration of young people from rural areas to cities, multi-cropping continuity, and difficulties related to mechanisation.

In our study, we found that out of $100 \%$ of farmers who were cultivating coffee in their own land, $8 \%$ had also leased land for cultivation.

$60 \%$ of coffee farmers said they did not expect that their children would be interested in continuing the coffee farm, while $13 \%$ were not sure, as their children were still small or undecided as to whether they were interested or not. Only $13 \%$ were sure that their children would look after their coffee farms.

Most of the children of coffee farmers surveyed were well-educated. $36 \%$ of the children of the surveyed farmers were not living in Wayanad but had migrated to other cities in Kerala, India, or even abroad. One farmer mentioned, "Most children live with 
their families outside of Kerala now. Farming is performed by their parents still in Wayanad, mostly to maintain that land under farming. People don't expect any additional income from it, their children send money, and the parents just keep the land under farming for the sake of it. If we were to do it (farming) properly, after investing in labour and other costs, we would not get anything as profit."

Although all farmers surveyed practiced multi-cropping on their coffee farms, they had different opinions on its contribution towards the robustness of the system. For instance, while $8 \%$ of the farmers believed that the profitability of multi-crop farming depended on the intercrops, $8 \%$ believed that it depended on the size of the area.

Since growing coffee requires intensive labour-input for almost all of its operations, such as planting, fertilising, pruning, and harvesting, the scope for mechanisation is limited. This makes coffee farming vulnerable because of the problem of labour scarcity in Kerala.

\section{Robustness of Kole Wetland Rice Farmers}

In the Kole wetlands, $80 \%$ of farmers were landowners. Out of these, $2 \%$ cultivated rice also on leased land. $16 \%$ were cultivating paddies only on leased land. One farmer told us that he had decided to not take so much land for lease in the next season because of the losses incurred during the pandemic. Another one mentioned that he would not cultivate the land that he had leased in this year. To not cultivate at all was not seen as an option by farmers who owned their land. On the other hand, there were some farmers who wished to expand their rice farms and decided to take more land on lease.

In the Kole wetland rice farming category, 31\% of respondents mentioned that their children would look after their farm, 35\% of the respondents mentioned that they are not sure if their children would be interested, and another 35\% said their children are not interested in farming. We noticed that most farmers whose children showed interest in farming discouraged them to not rely only on farming. A farmer mentioned, "I encourage my children to have another stable job and then look after the farm on the side."

The robustness of Kole wetland rice farmers is mainly enhanced by the communal farming system that is practiced there. As many operations require cooperation between contiguous fields, the decisions on farm operations are taken by the PDS committee members. In total, 79\% of farmers believed that their PDS was doing a good job as the only institution helping them to do rice farming during the pandemic.

\section{Robustness of Homestead Farmers}

The robustness of homestead farmers is influenced by their reluctance to use migrant labour, the easy maintenance of most components of the farming system, and multi-cropping.

In the homestead agroforestry system, 84\% farmed their own land. 4 farmers leased additional land, while $4 \%$ of the farmers cultivated only on leased land.

In response to our questions concerning the future perspectives for this land use system, $38 \%$ of homestead farmers said that their sons and daughters were interested in farming and would continue to look after their farm, while $29 \%$ were not sure whether their children would continue farming and 33\% were sure that they would not.

One factor that impairs the robustness of the homestead farming system is the reluctance of farmers to use migrant labour. In total, $76 \%$ of the farmers use local labour to work in their homesteads, while $20 \%$ use a combination of local and migrant labour. However, migrant labourers were employed only for work in the paddy fields. Some farmers mentioned that they "did not trust the migrant labourers to do the jobs in the homestead farm very well". Only $4 \%$ relied exclusively on migrant labour for carrying out the operations in their homestead. This reluctance to employ migrant labour could lead to decreasing maintenance and productivity of the homestead, as there is a scarcity of local labourers in Kerala.

The easy maintenance of most components of the homestead system makes it a very robust system. Timber trees do not require any operations except for occasional watering in the summer season. This also applies to fruit trees such as mango and jackfruit. Although 
upper and middle-strata trees like coconut, arecanut, nutmeg, and cinnamon need regular watering, they do not need intensive fertilising once they reach a certain stage. Only banana and vegetables need to be harvested and replanted every season or every other season.

As was expected, $100 \%$ of the homestead farmers were engaged in multi-cropping. $78 \%$ of these farmers agreed that multi-cropping increased their income security even during the pandemic. "We don't have to rely on the success of one crop for our income, when we have multiple crops", one homestead farmer said. "When the price of one crop drops, I can get a better price for another crop", and "Multi-cropping helps me to reduce losses. I am able to withstand this crisis because I do multi-cropping" were common replies that we received when asking about multi-cropping.

\subsubsection{Adaptability}

The drivers contributing to the adaptability of each system were identified by analyzing the overall setting of the farming systems and whether the changes made within the system could lead to adaptation.

\section{Adaptability of Coffee Farmers}

The factors influencing the adaptability of coffee farmers were their decision to change farming methods, the high cost of irrigation inputs, the advanced age of farmers, and the lack of migrant labour in Wayanad.

The decision to change the farming method of a coffee estate cannot be taken easily. If coffee plants are not managed in a consistent manner, the yields decline over the next few years. Farmers mentioned that the bad effects of discontinuing established practices persist for 3-4 years. "Regular investments must be made in coffee", said one farmer.

Most smallholder coffee farmers in Wayanad depend on subsidies to invest in irrigation equipment, such as drip or sprinkler systems. This is aggravated by the fact that the rains have been erratic in Wayanad over the past few years and that coffee as a watersensitive crop requires timely irrigation. The high cost of irrigation inputs makes it difficult to change from rain-fed coffee to irrigated coffee.

The average age of coffee farmers interviewed in Wayanad was 57 years, within a range of 40 to 80 years. Age would make it harder for farmers to adapt to conditions of stress or shock.

Coffee farming is less dependent on migrant labourers from the north of India than the other farming systems in Kerala. One farmer relied on labourers from the adjacent state of Karnataka, whereas another farmer used labourers from the north of India for his rice farm only and not for his coffee farm. The labour scarcity could make it difficult for the coffee farming system to adapt to changing conditions.

\section{Adaptability of Kole Wetland Rice Farmers}

Factors influencing the adaptability of Kole wetland rice farmers included group decisions of the PDS, difficulty in changing markets for organic rice farmers, and difficulties in changing the seasons of cultivation.

The decisions made in participatory group meetings can make the Kole wetland system more adaptable without changing the structure of the system. Some operations are difficult for individual farmers but can easily be performed in collaboration, for instance harvesting with machines.

As there are only a few buyers for organic rice in India and especially Kerala, it is difficult to find new markets for organic farmers. Low demand and limited market access hinder the adaptability of organic Kole wetland farmers.

The state government has encouraged rice farmers in the Kole wetlands to grow two crops in a year instead of the usual one. The farmers say they are given enough subsidies in the form of subsidised seeds and organic fertilisers and governmental support in the form of fixed prices and easy access to markets to do manage two cropping seasons. Changing 
form one to to two cropping seasons is an indicator of the adaptability of the system and has increased farming income even during the pandemic.

\section{Adaptability of Homestead Farmers}

The adaptability of homestead farmers was influenced by their ability to change markets, the high age of farmers, and the ease of processing some farm outputs.

Homestead farmers changed their marketing methods with remarkable easey during the pandemic. While the crops produced in the homestead farm are normally used $t$ for daily consumption, they were often demanded directly from the farmers by the customers during the pandemic. Through this process, the involvement of middlemen, who usually take a significant commission, could also be eliminated. The perishability of some of their crops also forced farmers to find alternative markets quickly when their usual market options were inaccessible during the pandemic due to restrictions and transport problems.

The average age of homestead farmers was 59 years. Homesteads in Kerala are mostly looked after by people close to or after their retirement age, which in the government service in Kerala is at 56 years. This makes the adaptability of homesteads quite low, since decisions regarding risk management and new strategies could not be taken quickly by old farmers.

Homestead farming presents wider diversification options than the other studied farming systems. Value-addition can be performed more easily and sometimes independently, as was demonstrated by homestead farmers during the pandemic. One farmer started making jams, preserves, and pickles with his homestead produce to prolong the shelf life. Another farmer also started selling seeds of the crops he grows, since there was a wide demand for seeds in those months as many people started cultivating their own vegetables at home. Hence, diversification options remain open to ensure the livelihood of homestead farmers, even if the prices of the crops produced are low.

\subsubsection{Transformability}

Transformability is a long-term change. There were no common factors that helped or hindered transformability in response to shocks or stresses across the three studied systems, but different factors applied in each category.

\section{Transformability of Coffee Farmers}

The transformability of coffee farms was influenced by the difficulty of changing crop composition, increasing labour charges in Kerala, and intercrops becoming increasingly unprofitable because of crop diseases.

Changing farming operations is just as difficult as changing the structure of the coffee farming system, such as the marketing channels. The president of the Wayanad Coffee Growers Association mentioned that coffee is the only crop for which farmers are getting almost the same price as they were getting 20 years ago. He mentioned that the input charges for coffee farming are increasing, while the selling price is not.

To convert a coffee plantation into another crop is expensive. Therefore, the constantly low price of coffee is one reason that is hindering transformability. Another crop that is suitable for such locations is avocado. However, as the market for avocado is not anywhere near the growing area, transport is expensive and the fruit cannot be stored for long periods when ripe. The market for avocado is also volatile and does not give as a stable an income as coffee, pepper, or rubber. As pepper and areca nut are not reliable crops anymore because of the loss of yield due to diseases, farmers are looking for other suitable intercrops. One farmer mentioned that timber trees could be a good intercrop. However, the branches have to be pruned regularly to let in enough light for the coffee plants to flourish. One farmer mentioned that "most coffee farmers are planning to leave farming rather than thinking about including more crops on their farms".

The increasing labour charges in Kerala stand in the way of the transformability of coffee plantations in Wayanad. One farmer mentioned that even if he would like to 
transform his coffee farm into another crop, another land use, or even replant his older coffee trees with younger ones, this would require labour-intensive operations such as uprooting. The increasing labour charges in Kerala do not permit him to do this.

Coffee is currently the main crop for most farmers in Wayanad. After the diseases started destroying the main intercrops, pepper and arecanut, the only agricultural income has come from coffee-so much so that a farmer who used to harvest 10 quintals (1000 kg) of peppercorns now harvests hardly 2 quintals $(200 \mathrm{~kg})$. Hence, the returns from intercrops have lessened, increasing the dependence on coffee.

\section{Transformability of Kole Wetland Rice Farmers}

The transformability of Kole wetland rice farmers was influenced by the unsuitability of the Kole wetlands for mechanisation and the difficulties standing in the way of changing land use systems.

Some farmers were concerned about the mechanisation of rice farming in the Kole wetlands due to irregularities in the topography of some fields. Additionally, one farmer mentioned that planting with machines can only be performed if the soil also contains some sand components.

"But even if machines do come to Kerala", said one farmer, "they need 10-20 machines to finish the operations. Only then the operations can be completed in 1-2 weeks." Another problem with using machines during the rainy season is the lack of permanent roads in some places. "It's not good enough that the government says they are spending money on this (machines). Only if the farm road is good, machines will be successful, otherwise the machines will sink."

As the Kole wetlands are a special ecosystem that has been in use for paddy cultivation for at least the last 300 years, it would not be easy to change the composition of crops. At most, fish could be cultivated in the flooded fields or vegetables could be cultivated along the sides of the fields. Moreover, wetland conversion is discouraged, since wetlands are vital for controlling floods in Kerala.

\section{Transformability of Homestead Farmers}

Homestead farming is not easily transformable. Most homestead farmers sell coconut, areca nut, pepper, nutmeg, and timber regularly from the homestead, and some maintain annual crops along with tree crops in a large area. In the latter case, homestead farming is usually the main occupation of the farmers. Moreover, homestead farming is already a multi-cropping system in which components are easily added or taken away. The tradition of homestead farming and the benefits of multi-cropping are reasons for farmers to continue maintaining the system as such, and they are usually not seeking ways to transform its structure or feedback.

\subsection{Transforming Structures and Processes}

The structures that enable or constrain the ability to secure livelihoods of farmers include the different levels of government and the private sector. The processes are the laws, policies, and culture relating to the farming system and farmers.

A common local institution that was found to be an active player in aiding transformation across all three farming categories was the Krishi bhavan, which comes under the state government's Department of Agriculture. Every panchayat has a Krishi bhavan in Kerala. During the pandemic, $89 \%$ of farmers from all categories specified that their Krishi bhavan had given them adequate support to navigate the crisis. In some panchayats, the Krishi bhavan has divided the cropped area into clusters. There is a committee constituted of farmers that looks after the needs of every cluster. For each cluster, they had a revolving fund, which is an interest-free fund renewed every 4 months. This fund came into particular use during the lockdown for 11 of the 90 farmers surveyed. In another panchayat, a farmer reported that the Krishi bhavan provided farmers with Rs. 6000 (79.92 USD) per acre as a pandemic relief fund for those who farm less than 5 acres. The Krishi bhavan also gives 
subsidies for inputs such as drip irrigation and seeds for paddy cultivation, which in $78 \%$ of the Kole farmers cases were not delayed or cancelled. Coffee farmers mentioned that the Krishi bhavan provided advisory services for intercrops grown with coffee. They also gave subsidies for organic fertilisers and free soil tests.

\subsubsection{Transforming Structures and Processes of Coffee Farming}

The local coffee board, which is an extension of the Coffee Board of India under the Ministry of Commerce and Industry, is the main government organisation from which farmers received support throughout the pandemic. In total, 33\% of interviewed farmers reported that they had received help from the coffee board (Figure 3). One coffee farmer mentioned, "I feel that other than the coffee board (Government of India), no other external agency is providing anything (inputs or subsidies) for bettering coffee farming.". Another one said, "Although the coffee board officers are very helpful, they have their limitations. They can give us financial help only on the basis of the funds that the government allocates to them. And these funds are very little." In total, $17 \%$ of the surveyed farmers felt that the government of Kerala is not doing enough to promote coffee farming. On the other hand, $20 \%$ of the 30 surveyed coffee farmers reported easy access to loans from government banks.

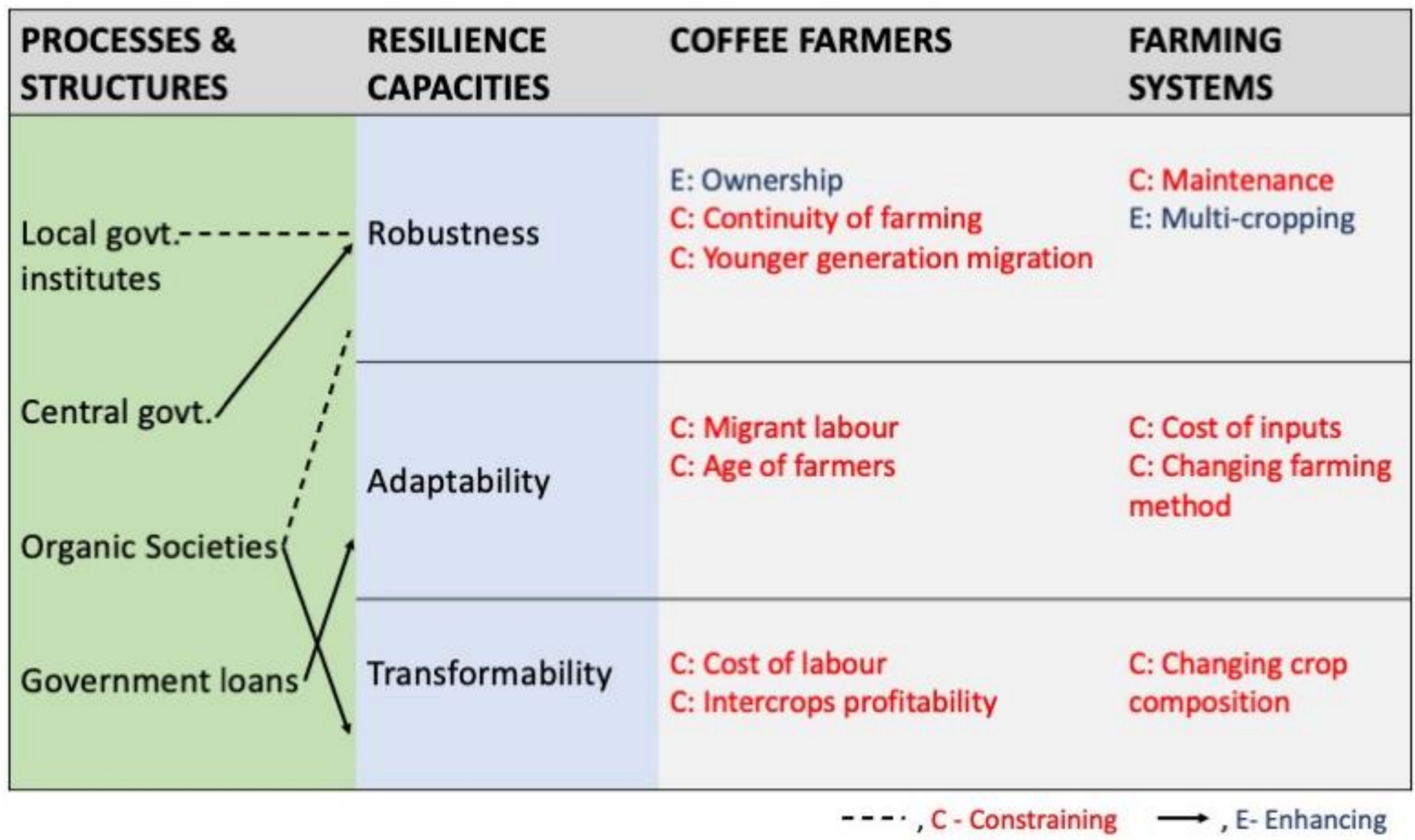

Figure 3. Resilience capacities, processes, and structures of coffee farmers.

There are organic societies that procure organic coffee beans from the farmers. They also provide inputs such as drying sheets and lime, although farmers stated that what they really need is financial help. To make organic cultivation financially successful, there must be financial compensation for decreased output. The standard for being "organic" is determined by the organisation and it takes 5 years of organic cultivation to obtain the organic certification. A common complaint about these societies is that they do not procure coffee beans according to farmer preference. When interviews were conducted, the organisation still had not procured this year's harvest. In addition, a critical voice said that adequate pricing for coffee is more important than support by the coffee societies. "There are many coffee societies in Wayanad but because there is no good price, they cannot do anything. And if there is a good price, we don't need all these societies.". 
The government of Kerala declared a base price for "Wayanad-branded coffee" of Rs. 90 (1.2 USD) in January 2021, which has not yet been implemented. The government has also supported labourers who could not be employed on coffee farms by distributing food kits.

\subsubsection{Transforming Structures and Processes of Kole Wetland Rice Farming}

In total, $78 \%$ of farmers believe that governmental support (local and state) has created a safety net for rice farmers in Kerala (Figure 4). Governmental support for rice farming in Kerala has been increasing over the years and was not reduced after the onset of the pandemic. A hike in base price, policies to cultivate more land under paddy farming, and the continued cooperation with the government procurement agency Supplyco have created a feeling of security among rice farmers. Government support has encouraged some rice farmers to do two crop seasons instead of one, even during uncertain times such as during the pandemic. It was reported that the local government provided farmers with an annual subsidy of Rs. 4000-6000 (53.27-79.92 USD) per acre. Organic farmers, on the other hand, complained that the subsidies given to them were not sufficient.

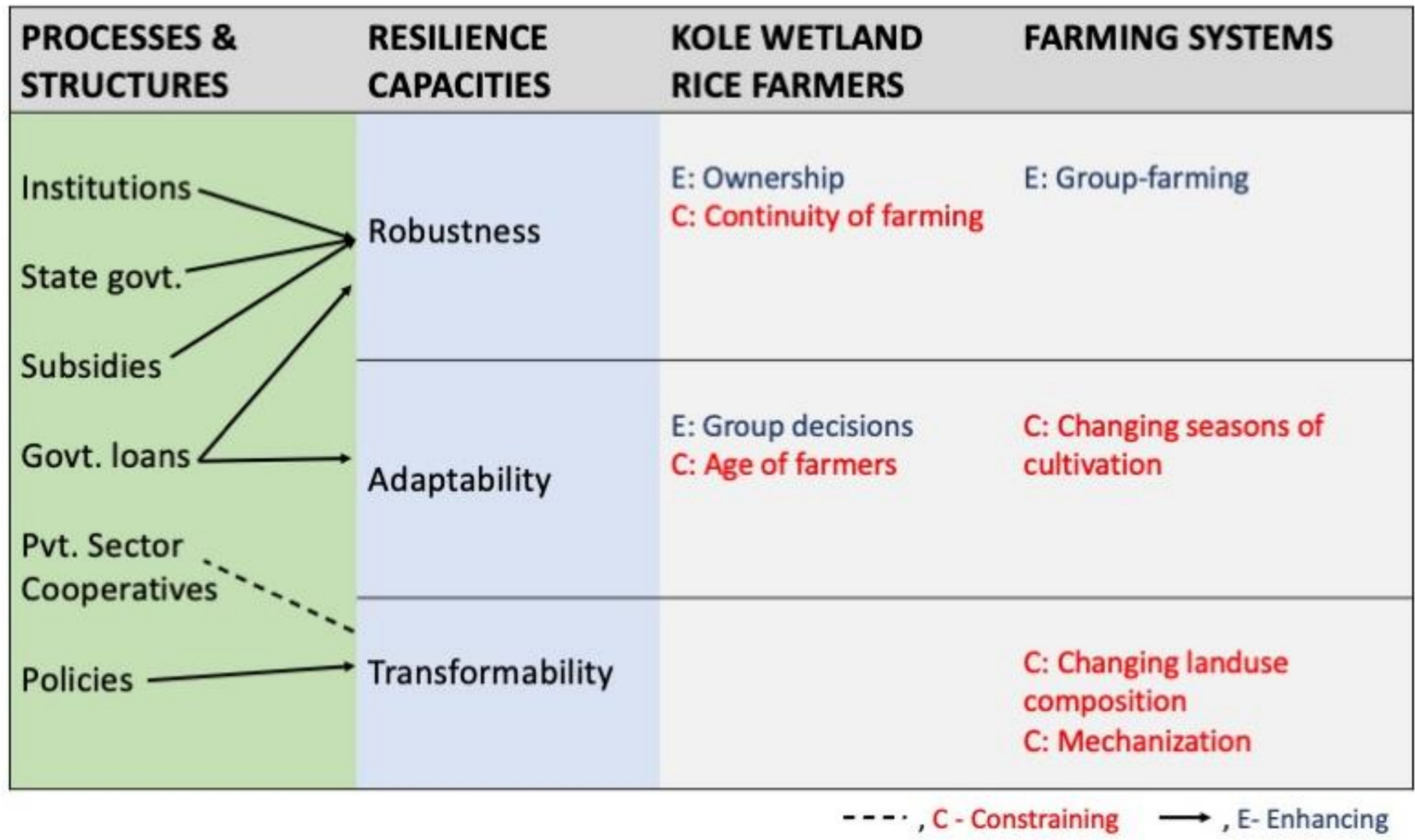

Figure 4. Resilience capacities, processes, and structures of Kole wetland rice farmers.

Money is also paid by the central government (5.33 USD per acre) and by the state government (1.33 USD per acre) if the farmers' rice fields are insured. The insurance policy is weather-based, and money is provided if weather parameters fall above or below a threshold for the optimum for rice.

One private sector cooperative structure involved in Kole wetland rice farming is a cooperative bank that has procured organic rice in Adat panchayat in Thrissur and sold it under the brand name "Jaivam Amrutham Organic Matta rice". However, organic farmers were rendered helpless when the bank could no longer procure rice after the pandemic began. After months of storage, the rice was finally procured at a reduced price. Private players such as these decrease the robustness of the system and make farmers want to move to other kinds of farming. One farmer who cultivates organic rice mentioned, "We have taken some measures to let the government know about our suffering. If this does not work, we are thinking about going back to conventional rice farming". 
Governmental support makes people want to continue conventional rice farming and decreases the transformability of the Kole wetland farming system. On the other hand, the lack of governmental support makes organic rice farmers revert to conventional rice farming. A farmer said, "There are no special policies or funds for organic farming. However, we could avail loans at minimal interest rates (4\%) from government banks." For agricultural loans, the state government declared moratoriums after the pandemic. Interest-free loans were also given.

To bring lands that have been laying fallow for many years under cultivation, the state government has implemented a particular policy. Farmers are provided an incentive of Rs. 35,000 (466.22 USD) if they start farming on fallow lands. Rice is the main crop that is being farmed under this scheme.

On 11 September, the government of Kerala made a policy to pay a royalty to owners of paddy farms to encourage them to retain their farms and continue farming. The royalty amount of Rs. 2000 (26.64 USD) per hectare was to be given to owners of 2.05 lakh hectares of paddy land in the state [54]. One farmer mentioned that she filled out the forms to receive the royalty but had not yet received the money.

\subsubsection{Transforming Structures and Processes of Homestead Farming}

The local Krishi bhavan offices were reported as the most useful institutions in providing help to homestead farmers during and before the pandemic (Figure 5). Many homestead farmers (26\% of surveyed farmers) are part of the VFPCK (Vegetable and Fruit Promotion Council Keralam), which is part of the Government of Kerala. In some areas, the VFPCK gave fixed prices for crops whose prices were dipping in the open market during the lockdown. There is also a risk fund that has been built up over the years and from which farmers received some money back during the pandemic. The VFPCK also gave sealed papers for easy transport of the agricultural produce during the lockdown. In one region, the VFPCK has a new scheme for transitioning towards organic farming. The central government was not mentioned by any of the farmers as being an aid or hindrance during the pandemic.

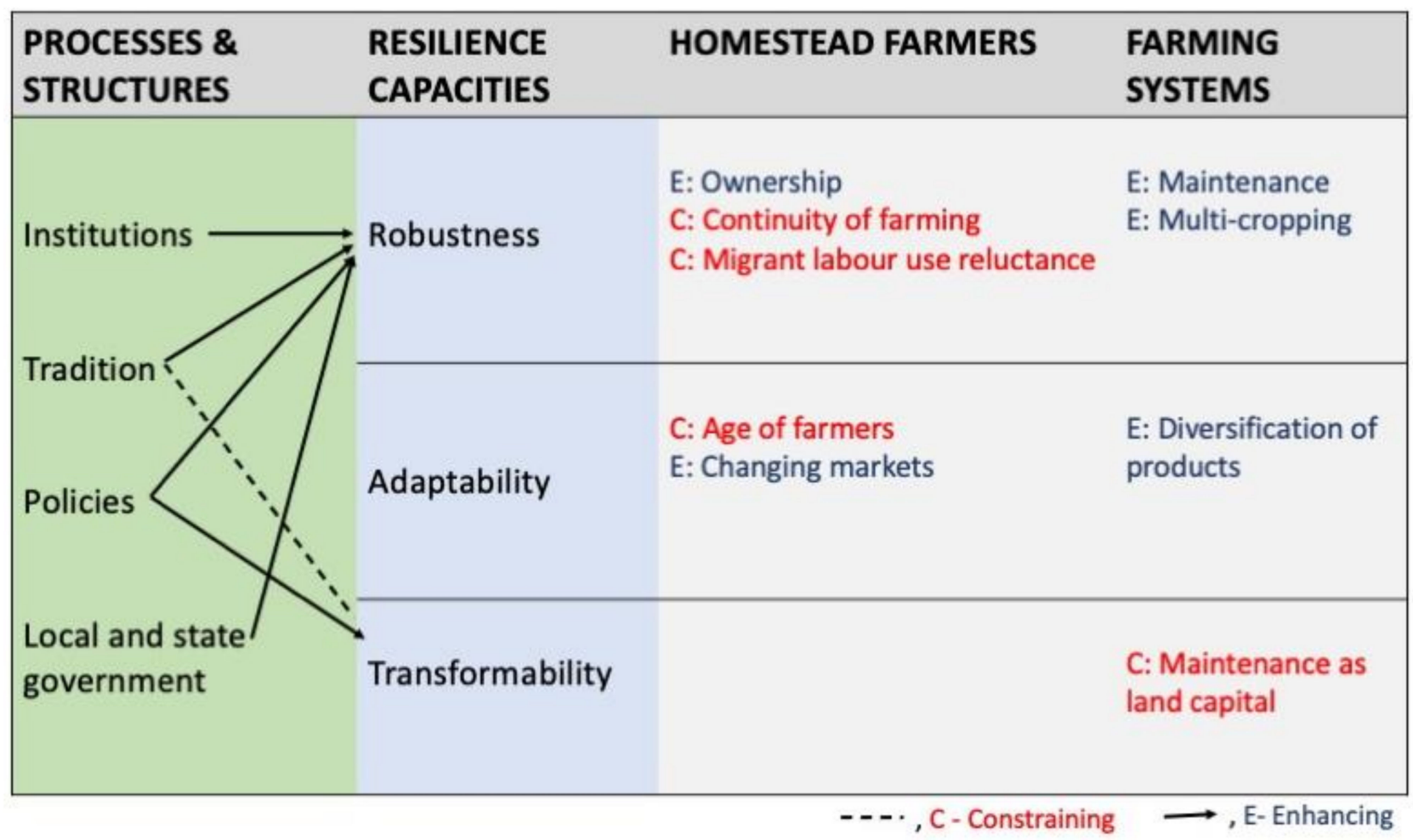

Figure 5. Resilience capacities, processes, and structures of homestead farmers. 
In total, $35 \%$ of homestead farmers said they did not receive any help from cooperatives or other private organisations. One farmer said, "we don't farm such crops that need to have cooperatives", while another said, "I don't have the time to participate in such things". However, $65 \%$ of the farmers said that help from the cooperative had helped them to get through the pandemic. One farmer also believed that "only with cooperatives, farming can be a success". A farmer's cooperative organisation in Amballur gave subsidies for organic farming, goat manure, and ground nut cakes. Other cooperatives such as Karshika Sahakarana Vikasana Board, Janatha Pachakkari Karshaka Samidhi, and the farmers' cooperative bank Ollur were also mentioned by the farmers as reliable institutions to help them get through the pandemic.

Laws and policies that impact the different crops farmed in the homestead also impact the whole system. Farmers benefit from policy measures such as increasing the procurement price of coconut to Rs. 32 (0.43 USD) per kg and schemes that set base prices for fruits and vegetables that are commonly farmed in homesteads, including tapioca, banana, ash gourd, bitter gourd, snake gourd, tomato, beans, and okra.

\section{Discussion}

A survey of the impacts of COVID-19 on livelihoods in India [6] found that those who were self-employed in agriculture were less affected than workers in construction, trade, hotels, or transportation. Casual labourers and non-agricultural respondents of the survey were the most affected by loss of work due to the lockdown. Although this is not surprising, since farmers continued farming on their own land during the initial stages of the pandemic, the medium- and long-term effects could be that continuity of farming is affected in the long-term due to the constraints on access to raw materials and labour.

The impacts of the pandemic varied in the current study across the three systems: Kole wetland rice, homestead, and coffee farming. For instance, only homestead farmers had to deal with surplus produce that they could not sell. It was found that in coffee farming, those who had storage facilities were able to store their beans for longer periods, whereas others had to settle with selling for lower prices. In a similar vein, a study co-designed by small-scale farmers in the global south (Indonesia and Southern Africa), has shown that the restrictions imposed by the countries against COVID-19 highlighted and partly exacerbated the existing socioeconomic inequalities among food system actors [55]. There were, however, a few impacts that remained constant across farming systems, such as the increased cost of labour, price drops of crops, transport bans, and working regulations.

As the impacts of the pandemic vary across the systems, the strategies used to cope with these impacts also vary. Astuti, Mutiara, and Hariance in 2021 [56] studied the livelihood strategies of farmers in Padang City, Indonesia, and found two types of livelihood strategies-survival strategies and collaborative strategies. Some of the survival strategies were employing labour despite the higher cost, finding new markets, changing the planting method of rice, and increasing the value-addition. In our study, we found collaborative strategies in communal Kole farming by farmers teaming up to bring in labourers, as well as the decision of organic farmers to revert to conventional rice farming. Some of these strategies were found to be short-term strategies, while some were long-term responses. The most important resource in Padang City was the family workforce, which in our case was true only for the homestead farming systems. A study on the perceptions of smallholder farmers regarding the impacts of COVID-19 on agriculture and livelihoods in Senegal farmers were concerned mainly about access to inputs, ability to plant, ability to feed and sell livestock, and ability to hire labour. There were also concerns regarding risks to food security, such as the risk of markets, which farmers regularly accessed, being closed or disrupted, and risk that food prices would increase [57]. A study analysing the resilience to COVID-19 of agrifood systems across 25 different countries in Asia found that the principal food systems were moderately resilient to the direct and indirect effects of the pandemic. The resilience was reinforced by government policies in countries that prioritised food availability and affordability. Disruptions to local labour markets, farm 
produce markets, and input supply chains were the main factors affecting rural livelihoods and food security [58].

Similar to the increased use of digital technology in the homestead category to create new marketing channels, digital technology was used by people in Austria during the pandemic to directly connect to local farms. Online platforms were used to build connections and farmers engaged in direct marketing by delivering the produce themselves. These examples both within our studied farming systems and across the world show how disruptive change can open up new possibilities and how quickly some famers can adapt [59]. The massive improvement in communication networks in India presents an opportunity to digitise information and bridge the gap between farmers and value chain actors by reducing costs and inefficiency [60]. For now, however, digital solutions are restricted mostly to advisory services and administrative formalities. It would be especially useful to have digital solutions for perishable goods. To avoid situations such as throwing away excess produce, it would be better if mobile procurement of perishable commodities was performed through farmer-producer companies, the National Agricultural Cooperative Marketing Federation of India (NAFED), corporations, or other aggregators in organised value chains [58]. Although these schemes might not be feasible in a small state such as Kerala, they could avoid produce being wasted to an extent and this could apply beyond the COVID-19 pandemic, as food wastage is a massive problem globally.

In the current study, farm diversification was applied to create a more stable system and protect against future risks. Hence, the farmers operate on "push" factors of diversification [61]. In 2021, Kumar and Uma [10] mentioned processing as a strategy for banana farmers to secure their livelihoods during the pandemic. Farm diversification is also an important strategy to create resilience against climatic shocks in farm production. Past exposure informs current diversification levels [61]. Hence, the adaptation strategies developed today could be drawn on later when farmers are faced with other crises in the future.

Removing stocking limits and allowing agro-processing enterprises and large private buyers to buy directly from farmers [62] are not well-suited for Kerala, and many farmers are skeptical about corporations entering into the agricultural markets. They feel this would create more competition and backward linkages with farms.

Resilience thinking teaches people to "expect the unexpected". The resilience of farming systems draws less on structural factors and more on creativity, mental agility, exploring possibilities, honing diverse skills, and using resources that can be repurposed and relocated [59]. Our case study provides examples of how farmers developed livelihood strategies for themselves and their farms to be more resilient in this manner. The diversification of products by homestead farmers, the decision of organic rice farmers to stop organic farming, and the gradual introduction of livestock by coffee farmers are telling examples from our study. With upcoming threats such as climate change, robust and decentralised food stocks and systems are recommended to be in place so that food systems are made resilient [60].

The COVID-19 crisis has brought out the inadequacies and challenges in the policies and structures of agricultural systems in India, as well as in the state of Kerala. Repurposing existing food and agricultural policies for resilient and healthier food systems could be much easier in the post-covid landscape. In the current study, homestead farmers sold in alternative markets, and all farming categories started using digital ways to market and sell their produce. This observation was reinforced by Kumar et al. (2021) [61], who explained that the key changes to be made in India's agricultural system post-pandemic are agricultural market reforms and digital solutions to connect farmers to markets, for the creation of safety nets, and for the provision of reasonable working conditions and decentralised food systems, especially for vulnerable communities.

We found that ownership and diversification contributed to the higher resilience of homestead farming. The commercial Kole wetland farming system, on the other hand, was found to be resilient because of the high level of governmental and institutional support. A 
similar trend emerged in a study of the impacts of the COVID-19 pandemic on agriculture and food systems in Nepal and the implications for SDG's [63]. The authors found that traditional subsistence systems were resilient with a higher potential to contribute to food security. They also found that commercial farming was more severely impacted due to the lack of access to local markets and because of the growing dependence on distant markets. In countries such Spain, family farms were found to be sufficiently resilient to provide a level of cushioning from the negative impacts of the pandemic [64].

Behura and Dash in 2020 [9], Kumar et al. in 2021 [61], and Timilsina et al. in 2020 [65] reported the early impacts of the lockdown and the pandemic on farmers in India. They reported problems such as rotten crops, financial crisis, and acute hunger amongst the farmers during the lockdown. Their recommendations included the use of automated machines such as seeding robots, harvesters, and drones, which could also be useful in some of our studied farming systems. They also recommend building the resilience of vulnerable farmers through direct financial support.

In our study, we found that a major reason for the robustness of the Kole wetland farming system was governmental and policy support, such as the marketing of rice through Supplyco. Although the greatest quantity of rice in Kerala was found to be procured by Supplyco, the organisation has been criticised in the past for procurement lags and late payments [64].

Multi-cropping, which is touted as a feature of innovative approaches such as agroforestry to build livelihood resilience [66], was found to be a key feature of two of the three studied farming systems. Multi-cropping provided additional income and food security and also improved the agrobiodiversity, thereby reducing environmental externalities and the need for off-farm inputs $[67,68]$. Multi-cropping could also act as a buffer for some of the environmental impacts of the COVID-19 pandemic that might occur later [69].

Studying the impacts of a shock can reveal the weaknesses of a farming system and help to identify policy recommendations for strengthening farming systems. This would also be useful in tackling long-lasting problems such as climate change. Although the pandemic will end someday, these recommendations can be used to ensure that the livelihoods of farmers are secure even in the face of other shocks and stresses.

\section{Strengths and Limitations of the Current Study}

The chosen case study represents three important farming categories, which are also representative agroecosystems in Kerala. The selection of the farming categories was a strength, as the crops grown in them make significant contributions to Kerala's agricultural economy. The coffee farming system also tells the story of a global pandemic impacting a small state through trade. The choice of the homestead category may be considered a weakness due to the variability within this category.

As data collection was performed remotely through phone interviews, we felt that some farmers were not comfortable with this situation and that possibly more information could have been extracted had the interviews been performed face to face. Additionally, focus group studies could not be conducted as planned due to travel restrictions caused by the spread of the delta variant.

The responses included all strategies that farmers had adopted to secure their livelihoods within the past year. Hence, some of them were also used to cope with factors other than the COVID-19 pandemic.

\section{Conclusions}

From the current study, it can be understood that the impacts of COVID-19 on the livelihoods of farmers differ across farming systems. Therefore, the strategies employed and outcomes achieved by these strategies also vary across the systems. Hence, it can be concluded that the support required for the different land uses requires differentiated treatment with specialised recommendations and solutions for each system. 
As the pandemic is still ongoing (as of November 2021), its immediate environmental impacts cannot yet be seen. However, land use changes, reductions in labour, the use of more livestock for income stability, and other changes due to the pandemic are bound to translate into environmental impacts that will need to be studied at a later point in time.

Author Contributions: Conceptualization, A.M. and D.S.-V.; methodology, A.M. and D.S.-V.; software, A.M.; validation, A.M.; formal analysis, A.M. and D.S.-V.; investigation, A.M.; data curation, A.M.; writing-origianl draft preparation, A.M.; writing-review and editing, D.S.-V.; visualization, A.M.; supervision, D.S.-V. All authors have read and agreed to the published version of the manuscript.

Funding: This research received no external funding.

Informed Consent Statement: Informed consent was obtained from all subjects involved in this study.

Conflicts of Interest: The authors declare no conflict of interest.

\section{References}

1. Andrews, M.A.; Areekal, B.; Rajesh, K.R.; Krishnan, J.; Suryakala, R.; Krishnan, B.; Muraly, C.P.; Santhosh, P.V. First confirmed case of COVID-19 infection in India: A case report. Indian J. Med. Res. 2020, 151, 490. [CrossRef] [PubMed]

2. The Times of India. Covid Deaths in India: India's Covid Toll in 2nd Wave Tops 2.5 Lakh, 1 Lakh More Deaths Than in 1st Wave. Available online: https:/ / timesofindia.indiatimes.com/india/covid-toll-in-second-wave-tops-2-5-lakh/articleshow/843932 69.cms (accessed on 5 August 2021).

3. Scroll.in. The Pandemic in Data: How Covid-19 Has Devastated India's Economy. Available online: https://scroll.in/article/99 9275/the-pandemic-in-data-how-covid-19-has-devasted-indias-economy (accessed on 6 August 2021).

4. Jakhotiya, G. Impact of COVID-19 on Indian economy and the road ahead. MPRA 2020. MPRA Paper No. 101456. Available online: https:/ / mpra.ub.uni-muenchen.de/101456/ (accessed on 6 August 2021).

5. Roser, M.; Ortiz-Ospina, E. Global extreme poverty. In Our World in Data; Global Change Data Lab: Oxford, UK, 2013; Available online: https:/ / ourworldindata.org/ extreme-poverty (accessed on 21 June 2021).

6. Kesar, S.; Abraham, R.; Lahoti, R.; Nath, P.; Basole, A. Pandemic, informality, and vulnerability Impact of COVID-19 on livelihoods in India. Can. J. Dev. Stud./Rev. Can. D'Études Dév. 2021, 42, 145-164. [CrossRef]

7. The Indian Express. Agriculture Policy Should Target India's Actual Farming Population. Available online: https:/ /indianexpress. com/article/opinion/columns/nabard-farmers-india-protest-agriculture-sector-7279331/ (accessed on 6 August 2021).

8. Parveen Jain, D.; Baghla, K.; Aditya, R. Effect of corona/COVID19 on the agricultural sector in India. World 2020, $2258909,154388$.

9. Behura, S.; Dash, D. Highway or Byway: Corona Virus Effect in Agriculture. Biot. Res. Today 2020, 2, 523-525.

10. Kumar, P.S.; Uma, S. Banana Processing: A Silver Lining during Corona Commotion. Biot. Res. Today 2020, 2 (Suppl. 5), 305-307.

11. Chathukulam, J.; Tharamangalam, J. The Kerala model in the time of COVID19: Rethinking state, society and democracy. World Dev. 2021, 137, 105207. [CrossRef]

12. Paul, N.; Jacob, E.M.; Philip, S.R. A Revisit to COVID-19 Challenges and Responses: A Case Study of Kerala. Space Cult. India 2020, 8, 47-61. [CrossRef]

13. Deccan Herald. Farm Laws May Have Limited Effect on Kerala's Existing Trade Systems, Feel Farmers. Available online: https:/ / www.deccanherald.com/national/south/farm-laws-may-have-limited-effect-on-keralas-existing-trade-systemsfeel-farmers-899143.html (accessed on 8 October 2020).

14. Department of Economics and Statistics Kerala. Gross Domestic Product of Kerala and India; Department of Economics and Statistics Kerala: Thiruvananthapuram, India, 2017. Available online: http://www.ecostat.kerala.gov.in/images/pdf/publications/State_ Income/data/gdp_1112_1516.pdf (accessed on 30 December 2021).

15. Rajana, A.S.; Chandrasekarb, K.S.; Marine Fisheries Sector. An Analysis of the Socio Economic and Feed Marketing Impact on the Farmers. In Proceedings of the 3rd International Conference on Management and Economics, Kerala, India, 26-27 February 2014.

16. Food and Agriculture Organization of the United Nations (FAO); World Food Programme (WFP). FAO-WFP Early Warning Analysis of Acute Food Insecurity Hotspots; FAO: Rome, Italy; WFP: Rome, Italy, 2020. [CrossRef]

17. Campbell, B.M.; Thornton, P.; Zougmoré, R.; van Asten, P.; Lipper, L. Sustainable intensification: What is its role in climate smart agriculture? Curr. Opin. Environ. Sustain. 2014, 8, 39-43. [CrossRef]

18. Maleksaeidi, H.; Karami, E.; Zamani, G.H.; Rezaei-Moghaddam, K.; Hayati, D.; Masoudi, M. Discovering and characterizing farm households' resilience under water scarcity. Environ. Dev. Sustain. 2015, 18, 499-525. [CrossRef]

19. Carpenter, S.; Walker, B.; Anderies, J.M.; Abel, N. From Metaphor to Measurement: Resilience of What to What? Ecosystems 2014, 4, 765-781. [CrossRef]

20. Yohe, G.; Tol, R.S.J. Indicators for social and economic coping capacity-Moving toward a working definition of adaptive capacity. Glob. Environ. Chang. 2002, 12, 25-40. [CrossRef]

21. Brown, K.; Westaway, E. Agency, Capacity, and Resilience to Environmental Change: Lessons from Human Development, Well-Being, and Disasters. Annu. Rev. Environ. Resour. 2011, 36, 321-342. [CrossRef] 
22. Smit, B.; Wandel, J. Adaptation, adaptive capacity and vulnerability. Glob. Environ. Chang. 2006, 16, 282-292. [CrossRef]

23. Acharya, R. Reduced Food and Diet Quality, and Need for Nutrition Services during COVID-19: Findings from Surveys in Bihar and Uttar Pradesh; IFPRI South Asia Office. Available online: https://southasia.ifpri.info/2020/07/09/15081/ (accessed on 30 December 2021).

24. Azim Premji University. COVID-19 Livelihoods Survey: Compilation of Findings; Azim Premji University: Burugunte Village, India, 2020.

25. Harris, J.; Depenbusch, L.; Pal, A.A.; Nair, R.M.; Ramasamy, S. Food system disruption: Initial livelihood and dietary effects of COVID-19 on vegetable producers in India. Food Secur. 2020, 12, 841-851. [CrossRef]

26. Jaacks, L.M.; Veluguri, D.; Serupally, R.; Roy, A.; Prabhakaran, P.; Ramanjaneyulu, G. Impact of the COVID-19 pandemic on agricultural production, livelihoods, and food security in India: Baseline results of a phone survey. Food Secur. 2021, 13, 1323-1339. [CrossRef]

27. Ceballos, F.; Kannan, S.; Kramer, B. Impacts of a national lockdown on smallholder farmers' income and food security: Empirical evidence from two states in India. World Dev. 2020, 136, 105069. [CrossRef]

28. Muthukumar, P.; Salini, R. Impact of COVID 19 on production and productivity of Kerala agriculture sector. IJISET-Int. J. Innov. Sci. Eng. Technol. 2021, 8, 155-162.

29. Anna, A.T.; Dinesh, K. The impact of the first wave of COVID-19 on the production indices pertaining to Vannamei shrimp farming in Kerala, India. Int. J. Fish. Aquat. Stud. 2021, 9, 200-205. [CrossRef]

30. George, J.; Babu, S.R. Farm tourism in the post Covid-19: A quick assessment of Kerala scenario. In Proceedings of the 1st Asian Tourism Research Conference, Kottayam, India, 1-3 December 2020; p. 440.

31. Rose, C.D.N.; Prema, A. Market. access and economic loss during Covid 19 lock down: The case of paddy farmers in Kerala. J. Krishi Vigyan 2020, 9, 232-237. [CrossRef]

32. Kangogo, D.; Dentoni, D.; Bijman, J. Determinants of farm resilience to climate change: The role of farmer entrepreneurship and value chain collaborations. Sustainability 2020, 12, 868. [CrossRef]

33. Abid, M.; Ali, A.; Rahut, D.B.; Raza, M.; Mehdi, M. Ex-ante and ex-post coping strategies for climatic shocks and adaptation determinants in rural Malawi. Clim. Risk Manag. 2020, 27, 100200. [CrossRef]

34. Kom, Z.; Nethengwe, N.S.; Mpandeli, N.S.; Chikoore, H. Determinants of small-scale farmers' choice and adaptive strategies in response to climatic shocks in Vhembe District, South. Africa. GeoJournal 2020, 1-24. [CrossRef]

35. Mulwa, C.K.; Visser, M. Farm. diversification as an adaptation strategy to climatic shocks and implications for food security in northern Namibia. World Dev. 2020, 129, 104906. [CrossRef]

36. ENVIS. Climate. Available online: http://www.kerenvis.nic.in/Database/CLIMATE_829.aspx (accessed on 13 August 2021).

37. Anil Kumar, N.P.; Khan, A.I.K.S.; Balakrishnan, V. Coffee, Climate and Biodiversity: Understanding the Carbon Stocks of the Shade Coffee Production System of India. In Handbook of Climate Change and Biodiversity; Springer: Cham, Switzerland, 2019; pp. 113-134. [CrossRef]

38. Malyadri, P. Status of coffee plantation in India: A high time for innovation and sustainability towards make in India. VSRD Int. J. Bus. Manag Res. 2016, 6, 47-50.

39. Karki, S.K.; Jena, R.; Grote, U. Fair Trade Certification and Livelihoods: A Panel Data Analysis of Coffee-Growing Households in India. Agric. Resour. Econ. Rev. 2021, 45, 436-458. [CrossRef]

40. Jayan, P.R.; Sathyanathan, N. Overview of farming practices in the water-logged areas of Kerala, India. Int J. Agric. Biol Eng 2010, 3, 28-43. [CrossRef]

41. Srinivasan, J.T. Understanding the Kole Lands in Kerala as a Multiple Use Wetland Ecosystem; Working Paper; Research Unit for Livelihoods and Natural Resources: Hyderabad, India, 2010.

42. John, J. Homestead Farming in Kerala: A Multi-Faceted Land-Use System. Rev. Agrar. Stud. 2014, 4, 80-94.

43. Salam, M.A.; Sreekumar, D. Coconut-based mixed farming system to sustain productivity. Indian Coconut J. 1990, 20, 1-3.

44. Mohan Kumar, B.; George, S.J.; Chinnamani, S. Diversity, structure and standing stock of wood in the homegardens of Kerala in peninsular India. Agrofor. Syst. 1994, 25, 243-262. [CrossRef]

45. John, J.; Nair, M.A. Socio-economic characteristics of homestead farming in south Kerala. J. Trop. Agric. 1999, 37, 107-109.

46. Andrews, S.S.; Kannan, E. Land Use Under Homestead in Kerala: The Status of Homestead Cultivation from a Village Study; Institute for Social and Economic Change: Bangalore, India, 2016.

47. Jaslam, P.M.; Joseph, B.; Mampallil, L.J.; Vishnu, B.R. Land Utilization under Homestead in Kerala: Current Status of Homestead Cultivation. Int. J. Curr. Microbiol. App. Sci 2017, 6, 5391-5410. [CrossRef]

48. Thomas, A.; Nithish Babu, M. Crowdsourcing Knowledge: An Extension Approach for Remunerative and Sustainable Home Garden Farming Systems in Kerala. J. Ext. Educ. 2020, 32, 6429. [CrossRef]

49. Meuwissen, M.P.M.; Feindt, P.H.; Spiegel, A.; Termeer, C.J.A.M.; Mathijs, E.; de Mey, Y.; Finger, R.; Balmann, A.; Wauters, E.; Urquhart, J.; et al. A framework to assess the resilience of farming systems. Agric. Syst. 2019, 176, 102656. [CrossRef]

50. Levine, S. How to Study Livelihoods: Bringing a Sustainable Livelihoods Framework to Life. Researching Livelihoods and Services Affected by Conflict; Secure Livelihoods Research Consortium: London, UK, 2014; pp. 1-23.

51. Department for International Development (DFID). Sustainable Livelihood Guidance Sheets; DFID: London, UK, 1999. Available online: https://www.livelihoodscentre.org/-/sustainable-livelihoods-guidance-sheets (accessed on 30 December 2021). 
52. Prasad, A.C. COVID-19: Coffee Farmers in Crisis as Indian Coffee Loses European Market. Available online: https: / / english.mathrubhumi.com/money/money-news / covid-19-coffee-farmers-in-crisis-as-indian-coffee-loses-europeanmarket-1.4677962 (accessed on 7 August 2021).

53. Vegetable and Fruit Promotion Council Keralam. Available online: http://www.vfpck.org/market_price.asp (accessed on 5 September 2021).

54. Manjula, M.; Devi, I. The Ecological Significance of Kerala's Move to Pay Royalty to Paddy Farmers. Available online: https: / / www.thenewsminute.com/article/ecological-significance-kerala-s-move-pay-royalty-paddy-farmers-138471 (accessed on 20 August 2021).

55. Paganini, N.; Adinata, K.; Buthelezi, N.; Harris, D.; Lemke, S.; Luis, A.; Koppelin, J.; Karriem, A.; Ncube, F.; Nervi Aguirre, E.; et al. Growing and Eating Food during the COVID-19 Pandemic: Farmers' Perspectives on Local Food System Resilience to Shocks in Southern Africa and Indonesia. Sustainability 2020, 12, 8556. [CrossRef]

56. Astuti, N.B.; Mutiara, V.I.; Hariance, R. Livelihood strategies of farmers in Padang City during pandemic Covid-19. IOP Conf. Ser. Earth Environ. Sci. 2021, 741, 012070. [CrossRef]

57. Middendorf, B.J.; Faye, A.; Middendorf, G.; Stewart, Z.P.; Jha, P.K.; Vara Prasad, P.V.; Stephens, E. Smallholder farmer perceptions about the impact of COVID-19 on agriculture and livelihoods in Senegal. Agric. Syst. 2021, 190, 103108. [CrossRef]

58. Dixon, J.M.; Weerahewa, J.; Hellin, J.; Rola-Rubzen, M.F.; Huang, J.; Kumar, S.; Das, A.; Qureshi, M.E.; Krupnik, T.J.; Shideed, K.; et al. Response and resilience of Asian agrifood systems to COVID-19: An. assessment across twenty-five countries and four regional farming and food systems. Agric. Syst. 2021, 193, 103168. [CrossRef]

59. Darnhofer, I. Farm resilience in the face of the unexpected: Lessons from the COVID-19 pandemic. Agric. Hum. Values 2020, 37, 605-606. [CrossRef]

60. Padhee, A.K.; Pingali, P. Lessons from a pandemic to repurpose India's agricultural policy. Nat. India 2020, 1-9. [CrossRef]

61. Kumar, P.; Singh, S.S.; Pandey, A.K.; Singh, R.K.; Srivastava, P.K.; Kumar, M.; Dubey, S.K.; Sah, U.; Nandan, R.; Singh, S.K.; et al. Multi-Level impacts of the COVID-19 lockdown on agricultural systems in India: The case of Uttar Pradesh. Agric. Syst. 2021, 187, 103027. [CrossRef]

62. Kumar, A.; Padhee, A.K.; Kumar, S. How Indian agriculture should change after COVID-19. Food Secur. 2020, 12, 837-840. [CrossRef] [PubMed]

63. Adhikari, J.; Timsina, J.; Khadka, S.R.; Ghale, Y.; Ojha, H. COVID-19 impacts on agriculture and food systems in Nepal: Implications for SDGs. Agric. Syst. 2020, 186, 102990. [CrossRef] [PubMed]

64. Food and Agriculture Organization of the United Nations (FAO). A Community of Farmers and Fisherfolk, a Community of Heroes; FAO Stories. Available online: https:/ / www.fao.org/fao-stories/article/en/c/1272559/ (accessed on 30 December 2021).

65. Timilsina, B.; Adhikari, N.; Kafle, S.; Paudel, S.; Poudel, S.; Gautam, D. Addressing Impact of COVID-19 Post Pandemic on Farming and Agricultural Deeds. Asian J. Adv. Res. Rep. 2020, 11, 28-35. [CrossRef]

66. Krishnankutty, J.; Blakeney, M.; Raju, R.K.; Siddique, K.H.M. Sustainability of Traditional Rice Cultivation in Kerala, India-A Socio-Economic Analysis. Sustainability 2021, 13, 980. [CrossRef]

67. Kandji, S.T.; Verchot, L.V.; Mackensen, J.; Boye, A.; Van Noordwijk, M.; Tomich, T.P.; Ong, C.; Albrecht, A.; Palm, C. Opportunities for linking climate change adaptation and mitigation through agroforestry systems. In World Agroforestry into the Future; World Agroforesty Centre: Nairobi, Kenya, 2006; pp. 113-122.

68. Kremen, C.; Miles, A. Ecosystem Services in Biologically Diversified versus Conventional Farming Systems: Benefits, Externalities, and Trade-Offs. Ecol. Soc. 2012, 17, 40. [CrossRef]

69. Priya, N.K.; Krishnankutty, J. Profile characteristics, inventory of the crop species and farming mechanisms in homestead farming of Kerala for agrobiodiversity conservation. ZENITH Int. J. Multidiscip. Res. 2013, 3, 30-37. 